Article

\title{
Analysis of Measures for Managing Issues in Post-Disaster Housing Reconstruction
}

\author{
Abdulquadri Ade Bilau *, Emlyn Witt and Irene Lill \\ Department of Civil Engineering and Architecture, Tallinn University of Technology, Ehitajate tee 5, \\ 19086 Tallinn, Estonia; emlyn.witt@ttu.ee (E.W.); irene.lill@ttu.ee (I.L.) \\ * Correspondence: abdulquadri.bilau@ttu.ee
}

Academic Editor: Chaminda Pathirage

Received: 30 September 2016; Accepted: 23 March 2017; Published: 28 March 2017

\begin{abstract}
After large scale disasters, reconstruction is often initiated by stakeholders to minimize disaster impacts and to mitigate a recurrence. For most reconstruction programmes, priority is given to reconstruction of permanent housing in consideration of the multiplying effects of housing reconstruction on social and economic recovery and the development of community resilience. However, numerous challenges arise during implementation which have reportedly been poorly managed and this has resulted in the ineffectiveness of housing reconstruction programmes and the failure of housing interventions to achieve their intended goals. In previous, related research, the issues affecting the implementation of housing reconstruction programmes were identified and a conceptual framework proposed. This study systematically reviews the academic literature, case studies and working papers in order to identify measures that have been applied by managers of reconstruction programmes to overcome these previously identified issues. The measures identified will be used to develop the previously proposed conceptual framework and thus to enable data collection through an experts' opinion survey. Findings from the experts' opinion survey will, in turn, be used to deduce best practice measures for managing permanent housing reconstruction programmes. This study is intended to aid policy making by providing stakeholders with good practice measures for managing issues in post-disaster housing reconstruction. In addition, it improves the knowledge base by presenting current housing reconstruction management practices and recommending how they can be improved for better community recovery and resilience building after large-scale disasters.
\end{abstract}

Keywords: built environment; community recovery; disaster resilience; housing reconstruction; natural hazards; reconstruction management

\section{Introduction}

While scientific research on global vulnerability to hazards, risk reduction and disaster resilience is on the rise, disasters continue to have severe consequences such as deaths, huge economic loses and social disorder. Impacts of disasters on the built environment lead to homelessness, mass population displacements and increased mortality [1-3]. Following disasters, considerable resources are often channeled to the reconstruction and recovery of affected communities [4], a substantial part of recovery funds being invested in permanent housing reconstruction $[5,6]$. Aside from being a visible investment choice, the reconstruction of permanent housing is considered the most effective means to return affected communities to better livelihood conditions [7-9] and providing safe and more secure housing to live in after temporary accommodation [10]. The reconstruction of permanent housing aids the empowerment of communities through the development of local capacities towards building resilient communities [8-10]. In addition, it promotes the redevelopment of the physical and social environment and facilitates the recovery of affected communities $[5,11,12]$. Further objectives 
for stakeholders' investments in housing reconstruction include the construction of hazard resilient structures, revival of household incomes, restoration of social order and the economic recovery of communities [12-14]. In summary, housing reconstruction, as a product, should produce good quality, resilient and acceptable dwellings [14] and, as a process, contribute meaningfully to the social and economic recovery and resilience development of beneficiary communities $[15,16]$. For the correlation between housing reconstruction and community recovery, see [17].

Due to the contextual characteristics of the post-disaster reconstruction environment and the outcome goals of most reconstruction programmes [18,19], a range of management issues arise in large-scale housing reconstruction programmes $[18,20,21]$. Implementing organisations' failure to adequately manage these issues results in the ineffective delivery of reconstruction programmes [22]. In earlier studies, we identified the management issues $[18,23]$. They include:

- Human resource issues

- Workmanship and quality management issues

- Monitoring and control issues

- Coordination and communication issues

- Logistics and supplies

- Health and safety issues

- Financial management

In the wake of calls for effectiveness in the management of large-scale housing reconstruction, the importance of drawing evidence-based measures from the literature to provide guidance for the management of (re)construction projects has been recognised [24]. Ulrich observed that a systematic review of the literature can provide information and insights into evidence-based measures to facilitate the fulfillment of stakeholders' expectations and achievement of projects' outcomes [25]. The identification and subsequent synthesis of evidence can inform the development of best practice measures [24] in order to provide effective guidance for the management of housing reconstruction programmes and facilitate the achievement of their intended outcomes.

This study involves a comprehensive desktop review of refereed articles, gray literature and case study reports from previous housing reconstruction programmes to identify measures applied in historical housing reconstruction programmes and to draw useful insights into the measures that could be applied to overcome the (previously identified) management issues that affect implementation of large-scale housing reconstruction programmes. The identified evidence of good management practice is synthesised and presented in the subsequent sections.

The methodology applied for this study is described in Section 2. The measures identified for managing each of the listed issues affecting housing reconstruction programmes' effectiveness as drawn from the literature are tabulated against their effects in Section 3. The synthesis of identified evidence measures is outlined and summarised process measures for managing each issue are presented as charts in Section 4. The conclusions drawn from the study are outlined in Section 5.

This study is premised on a trade-off between the centralized donor-led and beneficiary community driven, participatory approach [6] for large-scale housing reconstruction in low-income urban areas in developing countries.

\section{Research Methodology}

In conducting this study, a systematic literature search was conducted on six (6) selected electronic databases to collect journal articles, conference proceedings and case study reports on housing reconstruction programmes [18]. The databases were selected to ensure a wide collection of peer-reviewed literature. A combination of keywords generated from an overview of keywords used by peer-reviewed, case study literature on historical reconstruction programmes was used for the literature search. The search terminology as applied for title, abstract and keywords included: "permanent housing reconstruction programme" OR "post-disaster housing reconstruction projects" 
OR "housing restoration projects" OR "post-disaster housing recovery projects" OR "post-disaster rebuild" OR "housing reconstruction management". Limiters such as publication year, subject areas, document type, source title, industry, database were applied. The publication year for database search was limited to articles before November 2016. The output of the search is as shown in Table 1.

Table 1. Search results from academic databases.

\begin{tabular}{cc}
\hline Database & Articles Retrieved \\
\hline Scopus & 210 \\
Web of Science & 123 \\
EBSCO Host & 150 \\
Proquest Science (Journals) & 121 \\
Emerald & 70 \\
Science Direct & 158 \\
\hline
\end{tabular}

Collected articles were individually screened using their abstracts and, in other cases, the body of literature, to retrieve articles relevant to the study. Some articles collected through the keyword search were found to not be useful to the study as their content does not relate to the study focus. Articles identified as relevant to the study were exported into an EndNote X4 library.

Aside from the articles drawn from the academic databases, literature was also retrieved from a collection of humanitarian donor and practitioners' research networks. This was done by adapting the search terms used in the academic databases. Articles collected were screened for relevance and their citation details were entered into the Endnote library. The number of articles retrieved are as shown in Table 2. However, we observed that some papers retrieved from the databases had been earlier collected from the academic databases. With the aid of the EndNote software, duplicated references were removed. On deleting duplicates, 238 papers were established to be relevant to this study. Nonetheless, some literature that was found to be useful but not captured through the database search was also utilised. Of the 238 papers, some were left out because their focus was on temporary/transitional housing, while others were not used because the measures they identified were already captured. As a result, only 156 papers formed the body of literature. The distribution of the body of literature is as shown in Table 3.

Table 2. Distribution of literature retrieved from humanitarian practitioners' networks.

\begin{tabular}{ccc}
\hline Name & Website & Literature Retrieved \\
\hline Humanitarian library & www.humanitarianlibrary.org & 88 \\
ALNAP & www.alnap.org & 40 \\
ARUP & publications.arup.com & 11 \\
\hline
\end{tabular}

Table 3. Distribution of the body of literature.

\begin{tabular}{cc}
\hline Literature & Number \\
\hline Journal articles & 76 \\
Conference proceedings & 15 \\
Books (including working papers and books from donor websites) & 25 \\
Reports & 12 \\
Humanitarian practitioner/donor websites & 28 \\
\hline
\end{tabular}

Subsequently, a comprehensive desktop study was conducted to identify the measures that could be applied in managing each of the issues affecting effective implementation of large-scale housing reconstruction. The identified measures and their corresponding effects were collated, synthesised and presented in the form of a chart representing the basic process for managing each of the issues. 


\section{Measures for Managing Issues in Permanent Housing Reconstruction}

This section presents the measures that have been applied for managing each of the identified management issues that affect permanent housing reconstruction (as stated in Section 1). The tables below (Tables 4-11) present the measures and their effects on the achievement of housing interventions outcomes.

Table 4. Measures for managing human resource issues and their effects.

\begin{tabular}{|c|c|}
\hline Measures & Effects \\
\hline \multicolumn{2}{|l|}{ Needs assessment/planning } \\
\hline $\begin{array}{l}\text { Assess locally available skills } \\
\text { and capacities }[26] \\
\text { Plan construction team }[27,28]\end{array}$ & $\begin{array}{l}\text { Identifies local skills constraints, aids effective utilisation of } \\
\text { available resources/capabilities and facilitates the implementation } \\
\text { of housing reconstruction programmes }[14,26,27]\end{array}$ \\
\hline \multicolumn{2}{|c|}{ \{Recruitment and alternative recruitment strategies\} } \\
\hline $\begin{array}{l}\text { Mobilise and/or recuit local artisans, } \\
\text { construction workers, volunteers and } \\
\text { beneficiaries }[8,14,29]\end{array}$ & $\begin{array}{l}\text { Expands skilled workers supply [14,29]; Reduces labour costs [21]; } \\
\text { Facilitates indigenous skills and capacities [9,14]; Provides jobs and } \\
\text { livelihood support for affected communities }[9,14,30,31] \text {; Enables } \\
\text { acceptability and long-term sustainability }[14,29,32] \text {; Enables } \\
\text { beneficiary satisfaction }[5,16] \text {; Aids the spread of scarce resources } \\
\text { and minimises capital flight [33,34]; Enables beneficiaries to express } \\
\text { their needs [35]; Enables knowledge transfer [16,36]; Requires long } \\
\text { lead-time, delays production start-up and causes extended delivery } \\
\text { period [37,38]; Slows construction speed [37,38]; Yields inconsistent } \\
\text { housing quality [39,40]. }\end{array}$ \\
\hline
\end{tabular}

Helps to meet expertise, skills and competency demands [42,43];

Increases reconstruction costs [44]; Stabilizes escalating workers' wages [45]; Exacerbates housing shortage and causes rental price inflation [46,47]; Discourages community participation and deprives

Import workers $[8,29,41]$ locals of job opportunities [41]; Hinders acceptability, maintainability, socio-economic recovery and long-term sustainability of housing $[8,35,48]$;

Deprives beneficiaries of a sense of ownership [8,35,45]; Reduces knowledge transfer [36].

Provides skills, expertise, experience [42,53]; Facilitates reconstruction speed and efficiency $[8,42,54]$; Produces quality,

Engage construction industry actors [49-52] resilient housing $[8,42,53,54]$; Helps meet skills and capacity demands [51-53]; Enables knowledge sharing and local capacity development [42]; Does not resolve underlying socio-economic issues [8,54]; Denies beneficiaries a sense of ownership, acceptability and long-term sustainability $[8,35,45]$.

\begin{tabular}{|c|c|}
\hline \multicolumn{2}{|l|}{ \{Capacity development\} } \\
\hline $\begin{array}{l}\text { Educate and develop skills and } \\
\text { capacity of recruited workers [28]; } \\
\text { Supervise and mentor workers }[8,15] \text {. } \\
\text { Develop and utilise } \\
\text { multi-skilled workers [58] }\end{array}$ & $\begin{array}{l}\text { Expands skills supply, develops local capacities for effective } \\
\text { engagement, project sustainability }[8,31,32,55] \text {; } \\
\text { Aids effective knowledge transfer }[56,57] \text {. } \\
\text { Reduces costs, requirement for workers and increases workers } \\
\text { retention and earning potential }[49,58]\end{array}$ \\
\hline \multicolumn{2}{|l|}{ Motivation } \\
\hline $\begin{array}{l}\text { Provide timely remuneration [15] } \\
\text { and incentives [59]; Provide } \\
\text { appropriate accommodation }[43,46,60] ; \\
\text { Recognise and engage workers [27]; } \\
\text { Provide health and safety needs [61] }\end{array}$ & $\begin{array}{l}\text { Inspires enthusiasm and enhances workers' } \\
\text { performance [27,59];Enables retention of workers [27] }\end{array}$ \\
\hline
\end{tabular}


Table 5. Measures for managing workmanship and quality management issues and their effects.

\begin{tabular}{|c|c|}
\hline Measures & Effects \\
\hline \multicolumn{2}{|l|}{ \{Capacity development\} } \\
\hline $\begin{array}{l}\text { Assess and identify specific skill requirements and provide } \\
\text { requisite skills development programme for local artisans } \\
\text { and other workers }[8,29,41,62] \text {; } \\
\text { Provision of special training workshops for supervisory } \\
\text { (including beneficiary) and management personnel on } \\
\text { project inspection, supervision and enforcement }[37,62,63] \text {; } \\
\text { Provision of capacity development workshops for } \\
\text { management personnel [64] } \\
\text { Educate and sensitize participating organisations, artisans } \\
\text { and labourers on compliance }[62,63]\end{array}$ & $\begin{array}{l}\text { Helps to develop and deploy requisite skills and capacity required } \\
\text { for good quality workmanship and management }[8,29,37,41,62] ; \\
\text { Enables effective supervision, early fault identification, } \\
\text { quick remedial action and good quality workmanship [63]; } \\
\text { Imparts requisite skills required for quality workmanship } \\
\text { and management }[8,36] ; \\
\text { Enables adequate inspection at specified construction stages to } \\
\text { ensure compliance to set standards [64] }\end{array}$ \\
\hline \multicolumn{2}{|l|}{ \{Establishment and enforcement of standards\} } \\
\hline
\end{tabular}

Select and utilise only good quality materials

and components $[61,66]$

Provide detailed construction documents

and communicate changes [36,67]

Establishment and adherence to quality management plan

and quality assurance mechanisms [66,68];

Provide adequate supervision and technical monitoring to

ensure compliance and enforcement of standards and for

quality control [8,36];

Provide adequate field inspection $[44,69,70]$;

Test material quality, check specifications and ensure

adequate monitoring before issuing approvals or completion certificates [65,71].

\section{\{Institutional arrangements\}}

Ensure implementing organisations have requisite

knowledge and competencies for effective housing

production [72,73];

Establish procurement quality assurance mechanism [37];

Identify and review grey areas in contract

procurement process [37];

Ensure compliance to conditions of housing contracts [37]

Accredit and certify organisations to participate in

implementation $[59,74]$.

Table 6. Measures for managing monitoring and control issues and their effects.

\begin{tabular}{ll}
\hline \multicolumn{1}{c}{ Measures } & \multicolumn{1}{c}{ Effects } \\
\hline $\begin{array}{l}\text { Institutional/organisational arrangements\} } \\
\begin{array}{l}\text { Establish multi-tiered institutional arrangements—-dedicated management } \\
\text { organizational and geographical levels [57,60,62,75,76]; }\end{array}\end{array}$ & $\begin{array}{l}\text { Serves as project manager with structure and arrangements to } \\
\text { facilitate effective monitoring and control practices during } \\
\text { reconstruction [60,78]. } \\
\text { Deploy professionals and trained personnel and local representatives to } \\
\text { monitoring units (i.e., local govts/NGOs) [77]; } \\
\text { quality assurance [60] }\end{array}$ \\
\hline Set-up monitoring committees/work groups at local community level [79]; & $\begin{array}{l}\text { Brings about better monitoring during production [57,80] } \\
\text { \{Community participation\} }\end{array}$ \\
\hline $\begin{array}{l}\text { Constitute and deploy resident teams [80]; } \\
\text { Ensure beneficiary participation in monitoring process to ensure that } \\
\text { housing aligns with community needs and expected standards [15,45,81] }\end{array}$ & $\begin{array}{l}\text { Facilitates monitoring and control at local level [80] } \\
\text { Enables the alignment of buildings to beneficiary needs [15,82]; } \\
\text { Ensures beneficiary satisfaction [60] } \\
\text { better quality and acceptable housing [15,36,45,65,82]. } \\
\text { Ensures transparency [60]. }\end{array}$ \\
\hline
\end{tabular}


Table 6. Cont

\begin{tabular}{|c|c|}
\hline Measures & Effects \\
\hline \multicolumn{2}{|l|}{ \{Recruitment\} } \\
\hline $\begin{array}{l}\text { Recruit and deploy experienced management personnel or experts with } \\
\text { requisite technical managerial skills to adequately monitor and apply } \\
\text { control measures in reconstruction }[15,59,74] \text {. }\end{array}$ & $\begin{array}{l}\text { Enables achievement of on-time quality housing delivery [59]; } \\
\text { Experts are suitable to manage project monitoring, } \\
\text { evaluation and control systems for assessing work progress } \\
\text { and project control [83] }\end{array}$ \\
\hline \multicolumn{2}{|l|}{ \{Operational/implementation measures\} } \\
\hline $\begin{array}{l}\text { Establish housing reconstruction programme/project } \\
\text { implementation plans that include product quality management plan, } \\
\text { timescales and cost plan }[35] \\
\text { Provide adequate production plans }[30,59,62,84] ;\end{array}$ & $\begin{array}{l}\text { Basis for monitoring progress }[35,60] \text {. } \\
\text { Improved product quality and increase production output [85]. }\end{array}$ \\
\hline Set-out activities with long-lead times $[41,59,86]$ & Improves speed and efficiency of reconstruction process [85] \\
\hline $\begin{array}{l}\text { Supervisors should monitor implementation plans with local } \\
\text { communities' participation }[30,59,62,84] \text {; }\end{array}$ & $\begin{array}{l}\text { Enables compliance specification, quality, design and } \\
\text { integration of DRR measures }[41,86]\end{array}$ \\
\hline Establish monitoring and control and evaluation systems [83] & $\begin{array}{l}\text { Enables compliance with building codes quality standard, } \\
\text { timescale [83] }\end{array}$ \\
\hline $\begin{array}{l}\text { Conduct technical inspection and assessment }[8,64,83] \\
\text { Conduct technical auditing on new buildings [62,87]; } \\
\text { Provide corrective measure guideline [62] }\end{array}$ & $\begin{array}{l}\text { Ensures incorporation of risk reduction measures and } \\
\text { provision of good quality housing [62] }\end{array}$ \\
\hline
\end{tabular}

Table 7. Measures for managing coordination and communication issues and their effects.

\begin{tabular}{|c|c|}
\hline Measures & Effects \\
\hline \multicolumn{2}{|l|}{ \{Institutional arrangements\} } \\
\hline $\begin{array}{l}\text { Create or strengthen existing central } \\
\text { coordinating authority }[76,88-90]\end{array}$ & $\begin{array}{l}\text { To coordinate stakeholders' activities for optimal pull, allocation } \\
\text { and to ensure effective resource utilization }[76,90-92] ; \text { To manage } \\
\text { stakeholders and appropriately respond to their needs }[19,75,93] \\
\text { and the development of strategies to overcome challenges }[76]\end{array}$ \\
\hline $\begin{array}{l}\text { Set-up multi-level institutional/organi- } \\
\text { sational structure with units at different } \\
\text { operational levels }[75,76,88,89,94]\end{array}$ & $\begin{array}{l}\text { Enhances stakeholders' coordination }[75,76,94,95] ; \\
\text { Enhances the coordination of strategies and processes for } \\
\text { information and communication management }[75,76,94] ; \\
\text { Enables decentralisation of institutional structure }[75,76,94]\end{array}$ \\
\hline $\begin{array}{l}\text { Identify and incorporate local level } \\
\text { authorities [83], establish development } \\
\text { authorities or committees at } \\
\text { local/municipal levels }[8,14,89] \\
\text { Provide defined roles, lines of authority and } \\
\text { functions for personnel [83] and mandates } \\
\text { for stakeholders [96] }\end{array}$ & $\begin{array}{l}\text { Enhances stakeholders coordination and management of } \\
\text { reconstruction at local levels }[8,14,95] ; \\
\text { Facilitates local level cooperation, participation and } \\
\text { long-term alignment [83,95]; } \\
\text { Helps adapt the intervention to local needs and capacities [97] } \\
\text { It helps to identify personnel and stakeholders responsible for } \\
\text { different functions and responsibilities [98] }\end{array}$ \\
\hline \multicolumn{2}{|l|}{ Multi-stakeholder platform\} } \\
\hline $\begin{array}{l}\text { Form/create a multi-stakeholder platform } \\
\text { (MSP) or temporary organisation }[99,100]\end{array}$ & $\begin{array}{l}\text { Serves as coordinating platform for participating stakeholders [101]; } \\
\text { Enables collaboration of stakeholders with similar mandate and } \\
\text { interests [99,100]; Enables participation of stakeholders, } \\
\text { inclusiveness [93,102]; Ensures consensus on implementation } \\
\text { approach [93,102]; Helps resolve resourcing challenges and to } \\
\text { decide on better strategies to resolve emerging issues [32]; } \\
\text { Provides a medium for participatory governance for the } \\
\text { development of project implementation and monitoring } \\
\text { system [101]; Minimises lapses and duplication of efforts to aid } \\
\text { reconstruction efficiency [103]; Enhances transparency, } \\
\text { accountability [104]; Enables information, knowledge and } \\
\text { expertise sharing among stakeholders [60]. }\end{array}$ \\
\hline \{Capacity development\} & \\
\hline
\end{tabular}

\begin{tabular}{ll}
\hline $\begin{array}{l}\text { Train and educate management personnel } \\
\text { on coordination [37,88,105] }\end{array}$ & Enhances stakeholder coordination [37,105] \\
$\begin{array}{l}\text { Educate and sensitize stakeholders on } \\
\text { governing rules and regulations [60] }\end{array}$ & \\
\hline \{Needs assessment\} & $\begin{array}{l}\text { Enables effective stakeholder engagement [15,106,107]; } \\
\text { Helps to evaluate stakeholder needs and expectations for } \\
\text { effective support [15,108]; } \\
\text { Prevents misunderstandings in implementation [15,108]; }\end{array}$ \\
\hline $\begin{array}{l}\text { Identify, analyse and categorise stakeholders } \\
\text { based on their interests, challenges and } \\
\text { interconnections with others [15,106,107] }\end{array}$ & Facilitates stakeholder coordination [45] \\
\hline $\begin{array}{l}\text { \{Strategic coordination measures\} } \\
\text { Provide strategic coordination systems [45] }\end{array}$ & $\begin{array}{l}\text { Minimizes redundancy, wastage and resource overlaps, } \\
\text { ensures transparency and accountability [76,82,84,90] }\end{array}$ \\
\hline $\begin{array}{l}\text { Engage independent third party consultant } \\
\text { to monitor participating organisations' } \\
\text { activities [76,82,84,90] }\end{array}$ & \\
\hline $\begin{array}{l}\text { Conduct regular review and document } \\
\text { organisations' performance [76] }\end{array}$ & \\
\hline
\end{tabular}


Table 8. Measures for managing communication issues and their effects.

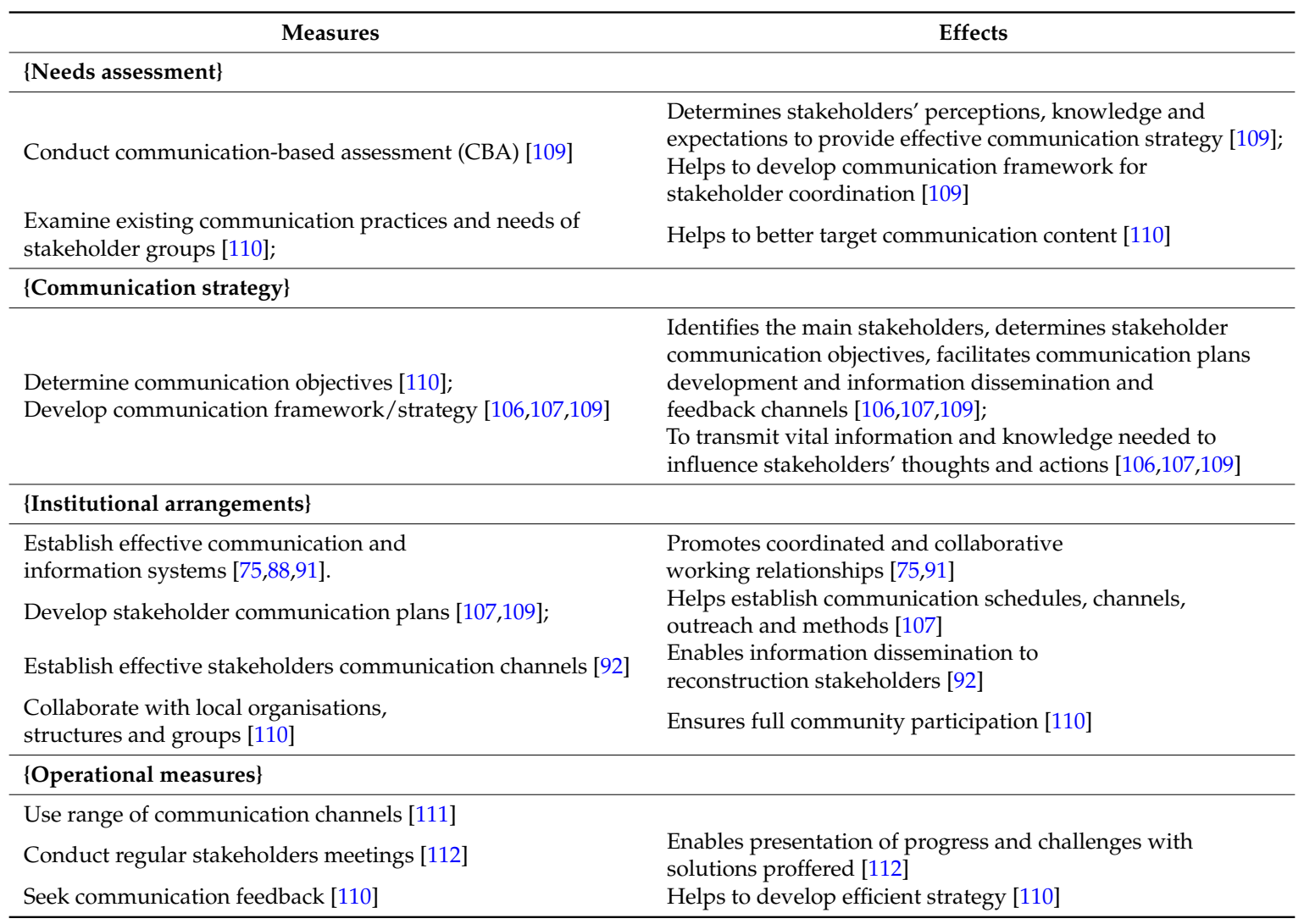

Table 9. Measures for managing logistics and supplies issues and their effects.

\begin{tabular}{|c|c|}
\hline Measures & Effects \\
\hline \multicolumn{2}{|l|}{ \{Recruitment\} } \\
\hline $\begin{array}{l}\text { Engage qualified and dedicated procurement experts } \\
\text { to manage resource procurement }[14,113,114]\end{array}$ & $\begin{array}{l}\text { Provides knowledge and expertise for effective management of } \\
\text { resource procurement [113] }\end{array}$ \\
\hline \multicolumn{2}{|l|}{ \{Capacity development\} } \\
\hline $\begin{array}{l}\text { Educate and provide continuous capacity training for } \\
\text { procurement personnel on effective assessment and } \\
\text { resourcing procedures }[113,115]\end{array}$ & $\begin{array}{l}\text { Enhances managerial, technical and administrative procurement } \\
\text { skills required to reduce resourcing challenges }[113,115]\end{array}$ \\
\hline \multicolumn{2}{|l|}{ \{Needs Assessment and planning $\}$} \\
\hline $\begin{array}{l}\text { Assess resource requirements based on sufficient } \\
\text { quality, availability, supply point and time of } \\
\text { resource need }[14,116]\end{array}$ & $\begin{array}{l}\text { Enables identification and selection of quality, sustainable and } \\
\text { acceptable resources for procurement [14,117]; } \\
\text { Enables scheduled and cost-effective resource delivery [118] }\end{array}$ \\
\hline Engage locals in resource assessment [14] & Helps to draw knowledge on locally available resources [14] \\
\hline $\begin{array}{l}\text { Identify and mobilise for resourcing with long } \\
\text { lead times [116] }\end{array}$ & $\begin{array}{l}\text { Ensures on-time delivery of resources }[116] \\
\text { Mitigates disruption of production process and its negative } \\
\text { impacts on project performance }[117,119,120]\end{array}$ \\
\hline $\begin{array}{l}\text { Map resource markets and make provision for price } \\
\text { variations due to seasonal variations }[26] \\
\text { and changing market conditions }[35,41]\end{array}$ & Aids effective resource delivery [35] \\
\hline \multicolumn{2}{|l|}{ \{Procurement arrangements\} } \\
\hline $\begin{array}{l}\text { Procure resources from available local and } \\
\text { regional markets }[9,55,121,122] ;\end{array}$ & $\begin{array}{l}\text { Facilitates revitalisation of local materials industries, markets } \\
\text { and transportation system }[9,55,121,122] . \\
\text { Facilitates local materials usage and preserves cultural identity } \\
\text { of community and local construction knowledge [115]. } \\
\text { Helps to minimise emissions from transportation. } \\
\text { Stimulates recovery of local economy [115] }\end{array}$ \\
\hline
\end{tabular}


Table 9. Cont

\begin{tabular}{|c|c|}
\hline Measures & Effects \\
\hline $\begin{array}{l}\text { Engage/incorporate locals in logistics and supply } \\
\text { chain functions [26] }\end{array}$ & $\begin{array}{l}\text { Creates multiplying effects for local population and helps } \\
\text { reinvigorate local economy [26,115]; Creates basis for further } \\
\text { investment in the local economy that helps to control material } \\
\text { prices and minimise freight movements on roads [123]; } \\
\text { Enhances local leaders' interest in the success of supply chain } \\
\text { operations [124]; Provides information on local geological } \\
\text { conditions that could impede effective resourcing }[125,126] \text {. }\end{array}$ \\
\hline $\begin{array}{l}\text { Engage resourcing experts with adequate } \\
\text { institutional arrangements [50-52] }\end{array}$ & Provides value for investment, saves time and costs [52] \\
\hline Examine and certify supplier capacity [127]. & Helps ensure supplier capacity to provide efficient delivery [127] \\
\hline $\begin{array}{l}\text { Provide information and communication } \\
\text { systems }[114,128,129] ; \\
\text { Provide essential services support } \\
\text { systems }[41,52,113,130]\end{array}$ & $\begin{array}{l}\text { Facilitates communication between parties and location tracking } \\
\text { helps to minimise logistics challenges }[114,128,129] \\
\text { Facilitates market linkage and scheduled and secured } \\
\text { resource delivery }[114,128,129]\end{array}$ \\
\hline \multicolumn{2}{|l|}{ \{Procurement approach options\} } \\
\hline $\begin{array}{l}\text { Multiple source procurement (resource procurement } \\
\text { through multiple suppliers) }\end{array}$ & $\begin{array}{l}\text { Results in stiff competition among resourcing organisations and } \\
\text { yields inflation in local economy [114,122,127]; Often results in } \\
\text { poor performance [127]; }\end{array}$ \\
\hline Single source procurement [129] & $\begin{array}{l}\text { Often provides effective supplier performance [109,131,132]; } \\
\text { Provides efficient and safe delivery of large volume of resources } \\
\text { for reconstruction [129]; Requires relatively longer delivery } \\
\text { period at higher procurement cost [129] }\end{array}$ \\
\hline
\end{tabular}

Table 10. Measures for managing financial management issues and their effects.

\begin{tabular}{|c|c|}
\hline Measures & Effects \\
\hline \multicolumn{2}{|l|}{ \{Needs assessment $\}$} \\
\hline Conduct needs assessment $[14,62,84,90]$ & $\begin{array}{l}\text { Identifies resource requirements for reconstruction }[14,84,90,133] \\
\text { Aids reconstruction resource mobilisation }[82,83,109]\end{array}$ \\
\hline $\begin{array}{l}\text { Engage local communities in assessments [62] } \\
\text { through ocal government/NGOs [8] }\end{array}$ & $\begin{array}{l}\text { Enables comprehensive community level assessments [62] } \\
\text { and beneficiary satisfaction in financial support [8] }\end{array}$ \\
\hline \multicolumn{2}{|l|}{ \{Multi-donor trust fund\} } \\
\hline Establish a Multi-Donor trust fund (MDTF) [92] & $\begin{array}{l}\text { Helps to pool donor financial pledges for } \\
\text { reconstruction projects [92]; } \\
\text { Improves coordination and effectiveness of } \\
\text { reconstruction processes [83]; } \\
\text { Helps minimise administrative costs [92]; } \\
\text { Provides framework for utilisation of donor funds [92] }\end{array}$ \\
\hline \multicolumn{2}{|l|}{ \{Institutional/budgetary arrangements\} } \\
\hline $\begin{array}{l}\text { Establishment of (independent or dependent) } \\
\text { reconstruction management agency }[83,134]\end{array}$ & $\begin{array}{l}\text { To make reconstruction funds more flexible and efficiently } \\
\text { responsive to reconstruction needs [83]; Allows for efficient } \\
\text { response to stakeholders' financial needs towards effective } \\
\text { project implementation [83] }\end{array}$ \\
\hline $\begin{array}{l}\text { Provide housing reconstruction budget through } \\
\text { communities' government's budget system }[6,83]\end{array}$ & $\begin{array}{l}\text { Provides spending schedules and details } \\
\text { Ensures transparency and accountability and } \\
\text { donor confidence }[6,83]\end{array}$ \\
\hline $\begin{array}{l}\text { Establish special finance mechanisms to provide for } \\
\text { flexible reconstruction funds disbursement [83] }\end{array}$ & $\begin{array}{l}\text { Provides auxiliary mechanism for reconstruction financing other } \\
\text { than government budgetary system [83] To provide effective } \\
\text { disbursements and allocation of funds for reconstruction [83] }\end{array}$ \\
\hline $\begin{array}{l}\text { Commission international consultant to coordinate and } \\
\text { monitor reconstruction financing [135]. }\end{array}$ & $\begin{array}{l}\text { Enables effective financial resource utilisation where disaster } \\
\text { affects communities' institutional structures and/or capacities [83] }\end{array}$ \\
\hline $\begin{array}{l}\text { Confirm credibility, monitor and facilitate receipt of } \\
\text { donor funds }[29,83,136]\end{array}$ & $\begin{array}{l}\text { Mitigates delayed disbursements [56] } \\
\text { Facilitates timely remittance of financial pledges and } \\
\text { resource needs }[83,136,137]\end{array}$ \\
\hline
\end{tabular}

Provide financial monitoring, evaluation and control system $[83,138]$

Provide independent monitoring mechanism [37] Incorporate municipal/area councils in financial monitoring and evaluation [138]

Publicise financial evaluation reports [138]

\section{\{Operational measures\} \\ Establish accreditation system for financial accounting and reporting using standards [138];}


Table 11. Measures for managing health and safety issues and their effects.

\begin{tabular}{|c|c|}
\hline Measures & Effects \\
\hline \multicolumn{2}{|l|}{ Vulnerability assessment and hazard mapping } \\
\hline $\begin{array}{l}\text { Undertake multi-hazard vulnerability assessment of } \\
\text { reconstruction sites [63,140-142]; }\end{array}$ & $\begin{array}{l}\text { Helps to identify disaster risk factors, hazard types, their } \\
\text { severity and the degree of exposure to them [63,140-142]; } \\
\text { Helps in the development of effective building codes and } \\
\text { regulations to guide design and development [63] }\end{array}$ \\
\hline Map hazards [63,140-142] & Identifies vulnerable areas within communities $[109,141]$ \\
\hline $\begin{array}{l}\text { Involve and ensure active participation of local community } \\
\text { in vulnerability assessment and hazard mapping [142,143]; }\end{array}$ & $\begin{array}{l}\text { Helps to grow local capacities for the development of } \\
\text { technically sustainable and acceptable solutions [142,144]; } \\
\text { Improves local management attitudes and enables risk } \\
\text { reduction behaviours and long-term cost effectiveness [144]; } \\
\text { Helps communities anticipate, respond and accept } \\
\text { assessment outcome and risk reduction measures }[143,145]\end{array}$ \\
\hline \multicolumn{2}{|l|}{ \{Establishment and enforcement of codes\} } \\
\hline $\begin{array}{l}\text { Provide legislation and regulations governing land-use } \\
\text { and building development [94,141] } \\
\text { Ensure compliance with land-use regulations [84,94,141] } \\
\text { Apply land use planning/zoning [146] }\end{array}$ & $\begin{array}{l}\text { Encourages application of land use acts and building } \\
\text { regulations [141]; Defines the public's role in ensuring the } \\
\text { safety of buildings and the environment [141] } \\
\text { Serves as a risk reduction measure that provides public } \\
\text { safety and protection of the environment [147] } \\
\text { Helps to restrict development in vulnerable areas and to } \\
\text { mitigate severe exposure to disaster risk [140] }\end{array}$ \\
\hline Relocate communities to safe areas $[71,140,148]$ & $\begin{array}{l}\text { Addresses severe exposure to ongoing risks and high } \\
\text { degree vulnerability to disruption }[71,140,148]\end{array}$ \\
\hline $\begin{array}{l}\text { Consider geological nature of resettlement site, access to sources } \\
\text { of livelihood, social and physical infrastructure and safety } \\
\text { prior to relocation }[14,148,149]\end{array}$ & $\begin{array}{l}\text { Enhances acceptability, facilitates community recovery } \\
\text { and helps to reduce disaster risk }[35,150]\end{array}$ \\
\hline New or improved building codes and guidelines $[53,94,140,147]$. & $\begin{array}{l}\text { Provides guidance for design, material selection and } \\
\text { production management practice to improve structural } \\
\text { quality and building performance }[53,94,140,147,151]\end{array}$ \\
\hline $\begin{array}{l}\text { Ensure compliance to building codes and guidelines and quality } \\
\text { assurance mechanisms through regular material quality testing [63]. }\end{array}$ & $\begin{array}{l}\text { Provides much needed safety of buildings and beneficiaries } \\
\text { and protects critical assets within the communities [141] } \\
\text { Enables buildings to withstand exposure to hazards [141]. } \\
\text { Provides confidence and assurance to investors on sound } \\
\text { investment decisions [141] }\end{array}$ \\
\hline \multicolumn{2}{|l|}{ Operational measures\} } \\
\hline Provide supervision, inspection, monitoring and enforcement $[63,71]$ & $\begin{array}{l}\text { Ensures housing production quality does not compro- mise } \\
\text { the codes, guidelines and designs provided }[63,71]\end{array}$ \\
\hline $\begin{array}{l}\text { Deploy health and safety personnel to assess } \\
\text { salvaged materials [112]; } \\
\text { Communicate health and safety concerns and measures [9,112] }\end{array}$ & $\begin{array}{l}\text { Reduces exposure of construction team and beneficiary } \\
\text { community to health and safety risk [112] }\end{array}$ \\
\hline $\begin{array}{l}\text { Ensure adherence to regulations on the use of } \\
\text { hazardous materials [121] } \\
\text { Educate workers health and safety risk } \\
\text { Ensure use of PPE [121] } \\
\text { Identify risk zones and place signs [121] }\end{array}$ & $\begin{array}{l}\text { Promotes safer reconstruction and protects the public } \\
\text { from hazard exposure [121] } \\
\text { Mitigates accidents, injury or loss of participants [152]; } \\
\text { Protects workers from exposure to site hazards [121] } \\
\text { Mitigates health and safety risks [121] }\end{array}$ \\
\hline
\end{tabular}

\section{Discussion}

Tables 4-11 contain the management measures referred to in the literature reviewed. In addition to these measures being grouped according to the seven previously identified management issues to which they correspond, they have also been tentatively classified within the tables according to the types of measures (needs assessment, recruitment, capacity development, operational measures, etc.) The intended purpose of the above tables is to directly report the measures as captured from the literature. There are undoubtedly gaps in this list of measures and these would need to be filled in order to describe a complete process of measures (i.e., a framework for management). The listed effects of the identified management measures that have been captured from the literature and therefore appear in Tables 4-11 are even less likely to be comprehensive. We note that some measures (e.g., 'Import workers' in Table 4) seem to invoke a relatively large number of effects, some of which are positive and others negative, while other measures (e.g., the 'Motivation' measures in Table 4) have relatively few listed effects for a larger number of measures. It seems that this ratio of effects to measures provides a rough guide to indicating how strategic the measure is. A highly strategic 
measure will be one which has many effects on the outcome of the reconstruction initiative while a less strategically significant measure will be one of a number of measures which may be taken to increase or reduce a particular effect on the overall outcome. This suggests a hierarchy of measures in terms of their effects.

In the following sub-sections, the measures are discussed in more detail and an attempt is made to organize them into management processes to deal with each of the seven identified management issues. These proposed processes take account of the temporal and hierarchical differences in the measures identified. They are represented in both narrative form and in flow charts. As many of the measures tentatively classified as 'Operational measures' in Tables 4-11 would be considered standard good practice in the management of construction projects (e.g., 'Establish project implementation plans that include product quality management plan, schedule of activities and cost plan' in Table 6), the proposed management processes refer primarily to the measures which enable the reconstruction production process and that are specific to the post-disaster context. Normal good practice measures for the actual production process of reconstructed housing are assumed to be followed within the reconstruction production process.

\subsection{Measures for Managing Human Resource Issues in Reconstruction}

Effective measures for managing human resource issues in reconstruction commence with the engagement of human resource experts with experience in housing reconstruction to conduct an assessment and planning of human resources requirements (both skilled and unskilled) that would facilitate the production of permanent housing.

Depending on the context, a number of strategies could be applied in resolving human resource needs for quick construction of resilient, sustainable and acceptable housing. These strategies include:

- Mobilisation and recruitment of local builders, skilled artisans, volunteers and/or beneficiaries;

- Engagement of construction industry actors, especially those in the reconstruction area who can utilise their connections to recruit skilled workers;

- The importation of skilled workers and experts; and,

- Development and utilisation of a multi-skilled labour strategy.

Regardless of the measures applied in sourcing for workers, workers' capacities should be developed to ensure they are adequately skilled to meet the emerging demands for production and long-term sustainability of the buildings. This can be achieved by providing education, training, sensitisation workshops and on-the-job mentorship. In this way, workers can develop requisite skills and competencies and they should be sensitised on the need to ensure the incorporation of risk reduction measures during housing production.

To invigorate workforce performance, workers should be motivated. This should inspire enthusiasm, enhance efficiency and greater performance and ensure their retention within the reconstruction organisation and area.

From the synthesis of evidence, Figure 1 shows the summarised process measures for managing human resource issues in large-scale housing reconstruction programmes. 


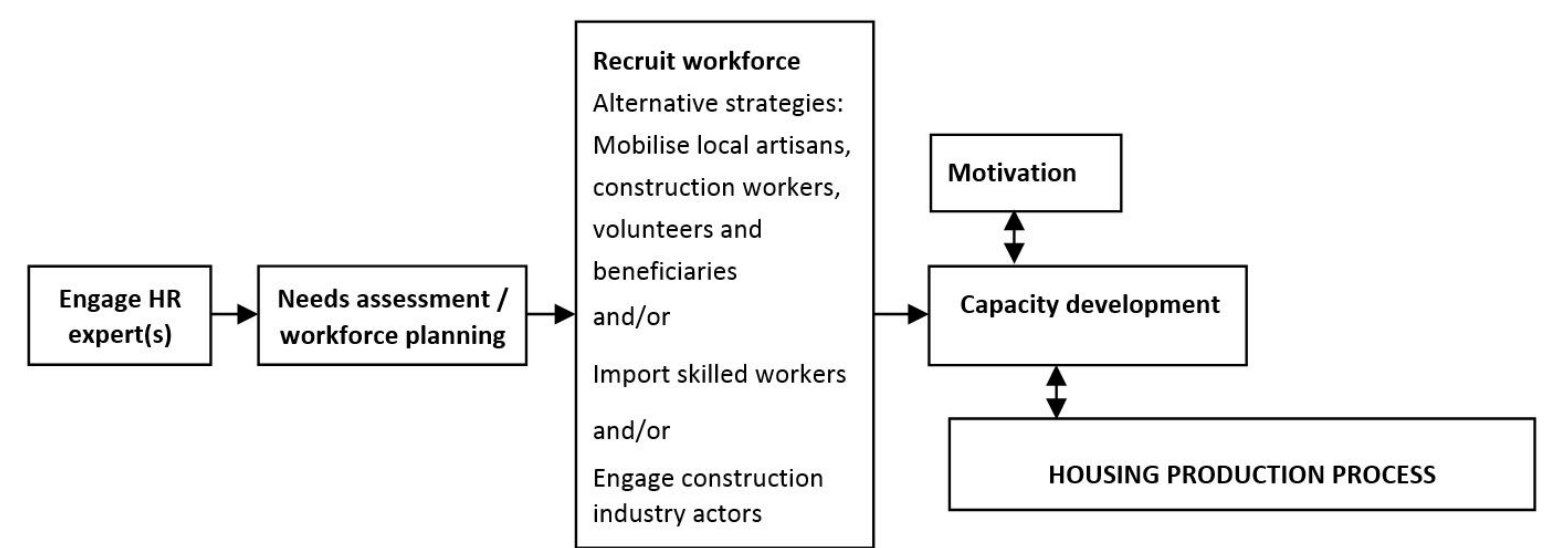

Figure 1. Measures for managing human resource issues in reconstruction.

\subsection{Measures for Managing Workmanship and Quality Management Issues in Reconstruction}

To ensure good workmanship and housing quality in reconstruction, it is crucial to conduct adequate assessments and identify the skills required for housing production prior to recruitment or the mobilisation of workers. For workers to meet emerging challenges and achieve set standards, training, up-skilling and technical skill development programmes should be provided for new recruits, artisans and other workers. Furthermore, special training should be provided for supervisory personnel including representatives of beneficiary communities to enhance their supervisory skills and to enable fault detection and swift corrective action. Capacity development and sensitisation workshops should be organised for inspectors and other management personnel to ensure quality inspection of work and compliance with guidelines and associated project requirements. It is also important that implementing organisations, artisans and labourers are adequately educated and sensitised on the importance of compliance to set standards.

As a measure for good workmanship and quality housing, the reconstruction management agency should provide new or improved building codes, technical construction guidelines, specification and quality management standards that show the minimum acceptable quality standard to ensure the provision of safe and resilient housing. Compliance to codes and guidelines must be ensured by setting out effective assessment procedures and systems for issuing building permits, approvals and completion certificates. Besides this, technical construction guidance should be provided with adequate field inspection including by beneficiary representatives during implementation to ensure compliance with construction standards. An effective quality management system which includes quality management plans and monitoring and control systems should be provided to ensure housing quality.

Considering the importance of providing detailed reconstruction documents and their effects on workmanship and construction quality, reconstruction organisations should be provided with detailed construction documents while updates or changes are effectively communicated to the site. Moreover, management and the implementing organisation should ensure the provision and utilisation of good quality materials and components to aid good workmanship and housing quality.

Quality management plans and quality assurance mechanisms including measures such as materials testing and specifications checks, workmanship quality control, adequate inspection and supervision by supervisory personnel should be provided.

It is crucial that implementing organisations have the requisite knowledge and competencies to avoid poor tendering and contract procurement processes. A procurement quality assurance mechanism should thus be established to identify and review grey areas in contract procurement processes and to manage the delivery of projects where contracts are awarded. In addition, organisations involved in the reconstruction should be accredited to ensure they possess the basic technical and managerial capacity required for participation. 
Based on the synthesis of evidence, a summarised process of the measures for managing workmanship and quality management issues in large-scale reconstruction is shown in Figure 2.

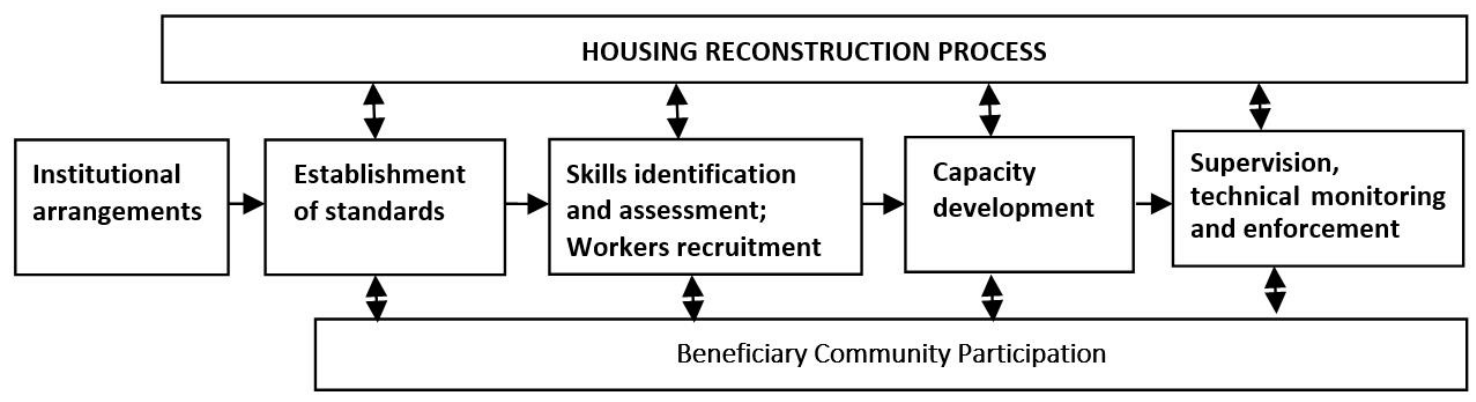

Figure 2. Measures for managing workmanship and quality management issues in reconstruction.

\subsection{Measures for Managing Monitoring and Control Issues in Reconstruction}

For large-scale housing reconstruction, multi-tiered institutional arrangements that facilitate monitoring and control effectiveness should be established. The institutional structure could be in the form of a dedicated management agency, regional authority, local monitoring and control units or committees at different organizational and geographical levels to enable effective monitoring and control of housing reconstruction. Experienced and trained personnel should be deployed across the structure to ensure effective monitoring and control during implementation.

Considering the importance of community participation in ensuring the alignment of reconstructed housing with the beneficiaries needs, community representatives should be engaged in the monitoring and control processes. Beneficiary participation facilitates the production of good quality and resilient housing, helps to monitor the implementation timeline and thus accelerates the housing implementation process and increases production.

Subsequently, monitoring and control during production can be ensured by establishing an effective monitoring, control and evaluation system to ensure better compliance to standards. The system may include local level work groups that monitor and evaluate housing production processes. The evaluation conducted by local level groups helps to achieve better project monitoring which often results in improved housing quality and reduced production time while ensuring the inclusion of the beneficiaries in the production and decision-making processes regarding their housing.

Implementing organisations should ensure that personnel deployed for monitoring and control are adequately skilled, experienced and certified to ensure monitoring and control effectiveness. The deployment of expert personnel for monitoring and control ensures adequate assessment of implementation plans, work quality and progress. Experts will tend to identify early warning signs and will provide measures for effective control towards timely, good quality and resilient housing delivery.

Implementation plans with realistic work schedules, quality management plans and budgets should be provided to serve as a tool for progress monitoring based on timeliness, resource utilisation and achievement of expected outcomes. In the development of production plans, activities with long lead times or affected by seasonal changes should be adequately considered.

As a measure for monitoring and control, technical inspection and assessment should be conducted to ensure compliance to building codes, construction guidelines and specifications at specified work stages before granting approvals or completion certificates. Besides, technical audits should be conducted on the buildings to ensure conformance to standards while corrective measure guidelines are drawn and implemented to effect corrections on defective buildings.

Figure 3 shows the summarised measures for managing monitoring and control issues in large-scale housing reconstruction. 


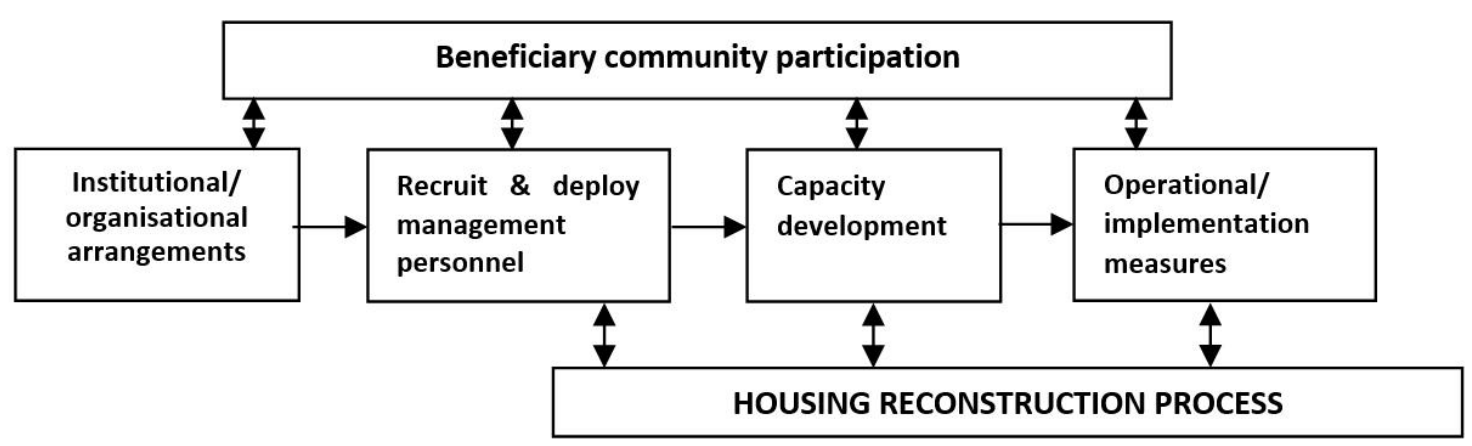

Figure 3. Proposed measures for managing monitoring and control issues in reconstruction.

\subsection{Measures for Managing Coordination and Communication Issues in Housing Reconstruction}

To coordinate the multitude of stakeholders involved in housing reconstruction, a central coordinating body in the form of a reconstruction authority should be established or strengthened to manage stakeholders' activities for optimal resource pull, allocation and utilisation and to agree on effective strategies to overcome emerging reconstruction challenges. The management agency should possess a well-defined institutional structure with operating units at different geographical and operational levels to enable decentralisation and effective stakeholder coordination and to enhance communication to participating stakeholders. Development authorities and/or committees may be established at municipal level to facilitate local community cooperation, engagement and participation and to ensure engagement of beneficiaries in the programme. Functions and lines of authority should be assigned and defined to operational level personnel to enable effective engagement and response to stakeholder needs.

Considering the importance of knowledge, skills and the capacity of personnel deployed for coordination, education, training and capacity development programmes should be provided for coordinating personnel to enhance their engagement and response to stakeholders and to enable them to make effective operational decisions in coordination. Sensitisation and enlightenment workshops should be conducted for stakeholders to understand the regulations and rules governing their activities and involvement in the housing reconstruction programme.

With the participation of several stakeholders often with varied mandates, interests and functioning levels, a multi-stakeholder platform (MSP) should be formed to ensure stakeholders collaboration and facilitate consensus building regarding the structure and the implementation strategy. The formation of an MSP would ensure the inclusiveness and active engagement of stakeholders towards the achievement of the housing interventions' intended outcomes. MSPs ensure participatory stakeholder governance that helps to resolve resource management challenges and enables operational efficiency, transparency and accountability.

For effective stakeholder engagement, it is important to identify, analyse and categorise stakeholders based on their interests, challenges and interconnections with other stakeholders. A critical analysis of stakeholders enables effective evaluation of stakeholder needs and expectations and helps to prevent potential misunderstandings among stakeholders.

Subsequently, a needs assessment should be conducted to identify resource requirements for housing reconstruction and to aid the development of a strategic reconstruction plan, coordinating and monitoring systems that identify and appropriately respond to stakeholder needs.

Tasks and responsibilities should be allocated to participating organisations and personnel and their performances should be regularly reviewed and appropriately documented. Moreover, independent third-party professional consultants should be engaged to monitor stakeholders' activities to minimise redundancy, identify overlaps and waste of allocated resources and to ensure transparency and accountability. 
Communication-based assessment (CBA) should be conducted to determine the perceptions, knowledge and expectations of key stakeholders so as to enable the development of a communication framework or strategy for effective stakeholder coordination.

An effective communication framework would identify the key stakeholders involved, determines communication objectives, facilitates the development of effective communication plans and would also identify appropriate channels for effective information dissemination and for the receipt of feedback.

An effective communication plan would include a stakeholder engagement plan, communications strategies, establishment of communication schedules, channels, outreach and adequate methods for stakeholder communication. It is, therefore, important for the reconstruction management agency and organisations to determine appropriate channels through which information reaches stakeholders, especially the beneficiaries.

A number of communication channels could be utilised depending on the stakeholders to be communicated with, the timeframe and expected results. Communications channels that could be used may include media channels and face-to-face communication. Collaboration with local organisations, community structures and groups would enhance effective communication with beneficiaries. It is important that feedback is adequately communicated to help in the development of better strategies and to achieve the intended outcomes of housing interventions.

A summarised process for managing coordination and communication issues in housing reconstruction is presented in Figure 4.

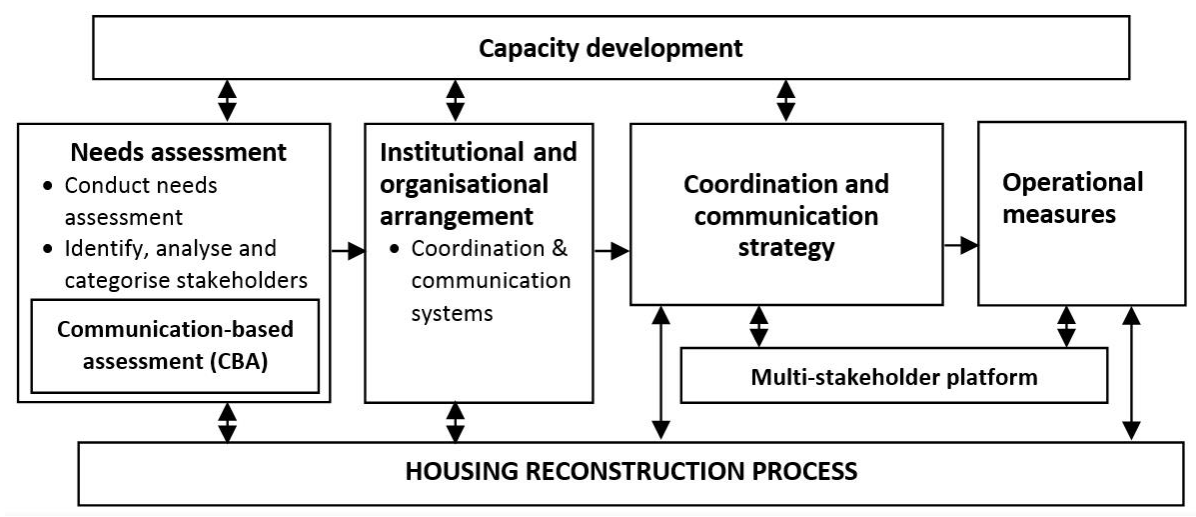

Figure 4. Measures for managing coordination and communication issues in housing reconstruction.

\subsection{Measures for Managing Logistics and Supplies in Housing Reconstruction}

One of the consequences of disasters is its impact on local construction markets that often results in resource scarcity and a hike in prices that affects availability of materials for reconstruction $[119,153]$. Besides, the disruption of transportation systems and networks compounds resourcing challenges in large-scale housing reconstruction $[113,120]$. It is, therefore, imperative that logistics and supplies are adequately managed to facilitate effective housing implementation.

In managing resource logistics and supplies in housing reconstruction, it is pertinent to engage dedicated in-house experts to oversee the management of resource supplies through effective assessment, planning, procurement, delivery and the management of resource needs for reconstruction [113]. Engaged experts would identify construction materials, components and equipment requirements especially those with long lead times, while their quantity, location and the timing of resource needs is established. Subsequently, adequate budgetary provision should be made with consideration for price inflation due to changing market conditions. Capacity development programmes should be organised for procurement personnel on effective assessment and resourcing procedures and on managerial, technical and administrative procurement skills required to minimise resourcing lead times, procurement costs and on networking with key resourcing stakeholders. 
Considering the complexity and variability of the reconstruction environment and the impacts of disasters on construction markets, a critical assessment of the local availability of resources should be undertaken to determine the availability and sufficiency in quantity, their environmental implications and cultural acceptability, resourcing and distribution costs and affordability, while markets for which resources are available are mapped. A thorough assessment would provide information on capacity of available markets to meet supply requirements and possible embargoes or legislation that may affect resourcing. Assessment outcomes should provide information on the robustness or vulnerability of transportation infrastructure systems and their impacts and possible alternatives. Resourcing assessment would also identify resourcing limitations and the need for strategic interventions such as key material importation and improvements in local manufacturing capacity to enhance logistics and supplies for reconstruction. Close consultation with the local communities during assessments is crucial in order to draw information and knowledge of the local community and environment.

Adequate planning is crucial for effective logistics and supplies operations that would ensure resource availability, quality and selection of acceptable resources, cost-effectiveness in supplies and scheduled delivery of resources. In planning for supplies, resource requirements should be identified and established based on specification, quantity, supply points and time of need, while resources with long lead times should be identified and prioritised. Adequate budgetary provision should be made with consideration for contingencies that may arise due to increasing demands and changing market conditions.

Due to the interrelationships between housing reconstruction, livelihood provision and socioeconomic recovery of beneficiaries, resources should be largely procured from available local and regional markets considering its effects on local materials production, revitalisation of local industries, markets and the transportation sector. Locals should be engaged in resource logistics and supplies to boost the recovery of the affected local economy as witnessed during reconstruction in Kosovo [115]. The engagement of local suppliers in housing reconstruction has tremendous benefits for the local community including job creation and income generation. It reinvigorates the affected economy while encouraging further investments for community development to be created due to continuous resource demand beyond the capacity of local markets. Evidence has shown that resourcing from local markets facilitates the use of local materials which is most desirable considering socio-cultural appropriateness, acceptability, ease of maintainability and long-term sustainability [14]. The expansion of the local construction materials industry helps to control local material prices and minimises the movement of freight on roads [123].

Considering that resource procurement for large-scale housing reconstruction comes in significant quantities and the inability of local markets to cope with demands [14], the challenges of inflation in the local economy or stiff competition among multiple suppliers/resourcing organisations which often results in poor supplier performance and with severe consequences for housing programmes' success $[114,122,127]$. It is, therefore, imperative that only experienced logistics and supplies experts with adequate institutional arrangements and capacity are engaged to ensure quality and scheduled resource delivery, save time, costs and provide value for donor funds. Single source suppliers to be engaged for large-scale housing should be examined and certified to have adequate capacity for efficient delivery. The examination of the supply could be based on previous experience and performance, communication efficiency, quality and timely resource delivery [127]. Some advantages of the single source resourcing approach include supplies efficiency, safe and protective delivery of large volumes of resources for reconstruction, restraint on unnecessary bureaucracy in logistics and a simplified supply chain. Nonetheless, the single source resourcing approach could be disadvantageous to organisations managing small sized housing due to the relatively longer delivery period and higher cost required for resource procurement [129].

Figure 5 shows a summarised process of measures for managing logistics and supplies in large-scale housing reconstruction. 


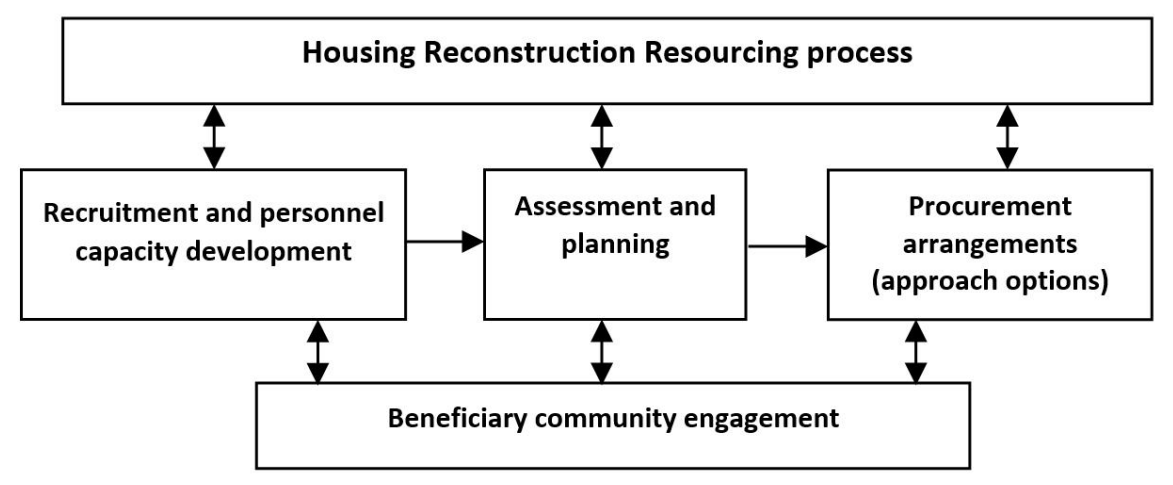

Figure 5. Measures for managing logistics and supplies in housing reconstruction.

\subsection{Measures for Managing Financial Management Issues in Housing Reconstruction}

Following large-scale disasters, external support is often sought by the government of affected communities from the international community, funding agencies and local organisations to provide recovery assistance in the form of outright gifts, donor funds, grants and long term loans for reconstruction. Despite the well-meaning intentions of the funding bodies, financial management in reconstruction has been problematic with consequences for housing reconstruction effectiveness.

Prior to implementation, a needs assessment is conducted to identify resource requirements for the reconstruction programme. The needs assessment is used by stakeholders to estimate and mobilise resources for reconstruction. However, the needs assessment does not reflect the financial estimate required for housing implementation. As a result, a housing reconstruction budget should also be drawn.

To minimise delays often encountered when utilising government budgetary systems, government's financing systems should be assessed to ascertain budget implementation, funds disbursement procedures and flexibility to enhance the reconstruction process [83]. An independent reconstruction management agency could be established to make reconstruction funds flexible and responsive to reconstruction needs or the creation of a different budgetary system for reconstruction operating outside the government budgetary framework that allows for effective response to financial needs. Special finance mechanisms can also be deployed to allow for the flow of reconstruction funds and to mitigate disruptions during housing implementation. Where disaster effects take a toll on affected communities' institutional capacities, international consultants may be commissioned to coordinate and monitor reconstruction financing for effective utilisation [135].

To finance large-scale reconstruction, the World Bank, on the advice of the government of affected communities, may establish a Multi-Donor Trust Fund (MDTF) to pool donor pledges to effectively finance reconstruction projects. Funding agencies also often recommend the provision of housing reconstruction budgets through governments' budgetary systems to ensure transparency, aid accountability and to inspire donor confidence. However, most government's budgetary systems are not flexible enough to allow for the rapid disbursement of funds that facilitates the housing reconstruction process. Moreover, housing reconstruction spending schedules rarely align with government appropriation cycles and this often causes disruption of the housing implementation process. The delayed financial disbursements and non-remittance of financial pledges by donors discourages the participation and cooperation of other stakeholders, affects phased resource procurement, impedes housing reconstruction start-ups, delays project implementation and subsequently affects quick recovery of communities. As a measure to minimise delay in remittance of donor pledges, the reconstruction agency should confirm credibility, monitor and facilitate timely receipt and disbursement of donor funds to mitigate disruption during housing implementation.

Corrupt acts, for example the misappropriation of funds, kickbacks for contract awards, bribing local communities to influence their acceptance of poor construction quality, are frequently perpetrated 
in reconstruction and they result in severe loss of scarce resources [5,154,155]. Transparency, accountability and trust on the part of reconstruction organizations are an essential basis for donors to provide reconstruction funds. For accountability, transparency and effective management of donor funds, local councils and community representatives should be involved in financial monitoring and evaluation. Detailed financial evaluation reports and receipts should be publicised by reconstruction organisations while independent monitoring mechanisms are instituted to ensure transparency, accountability and probity. Organisations managing reconstruction must demonstrate value for money through the scheduled completion of the housing project within acceptable standards.

Operational measures to mitigate misappropriation and corruption in reconstruction should be established and this may include the provision of incentives for personnel involved in reconstruction as rewards for a corrupt-free project, continuous assessment of corruption risk throughout the reconstruction programme, the creation of a unit with motivated personnel within the reconstruction management structure to monitor resource utilisation, investigate and penalise corrupt and fraudulent practices, blacklisting and debarment of organisations or personnel guilty of corruption or fraud [156]. Also, the adoption of the "whistleblower" mechanism, where confidentiality and protection is offered to personnel that report corruption.

Based on the synthesis of evidence, the process measures for managing financial issues in large-scale housing reconstruction are presented in Figure 6.

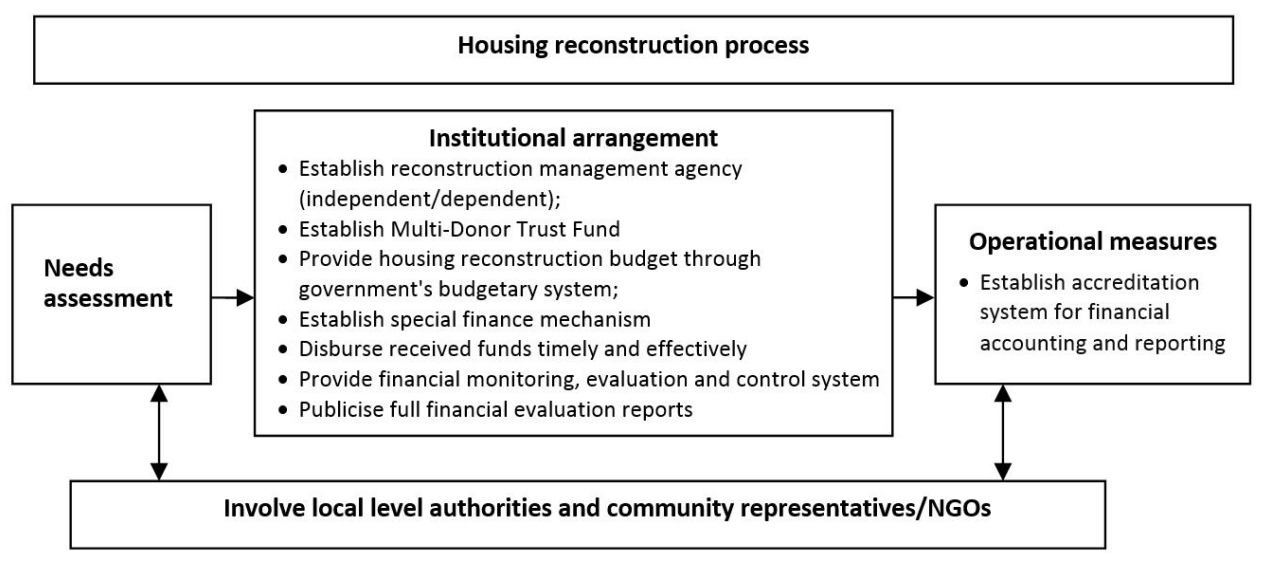

Figure 6. Measures for managing financial issues in large-scale housing reconstruction.

\subsection{Measures for Managing Health and Safety Issues in Post-Disaster Housing Reconstruction}

Several concerns arise in the post-disaster context including those of health and safety of buildings, reconstruction workers and beneficiary communities. To improve safety and health in reconstruction, an integrated approach is required.

Applying an integrated approach to ensure the safety of buildings and the community from vulnerability to natural hazards involves undertaking a multi-hazard vulnerability assessment to identify underlying disaster risk factors, types of hazards, their severity and the degree to which the reconstruction site is exposed to hazards. Hazard mapping helps to identify and prioritise highly vulnerable communities for possible retrofitting or eventual resettlement. The assessment and evaluation of underlying risk factors and lessons learnt from the behavior of affected buildings due to disaster effects and outcomes of diagnostics surveys aids the development of effective building codes and regulations that guide the development of safe and resilient housing. However, beneficiary communities' representatives should be trained and engage in vulnerability assessment and hazard mapping in order to build local capacities for the development of technically sustainable and acceptable solutions that can sufficiently respond to health and safety risk and in creating local community cultures and management approaches towards cost effective risk reduction. 
To better translate vulnerability assessment and hazard mapping into risk reduction and subsequently a resilient and safe community, adequate land-use and building development legislation and regulations should be provided to encourage and enforce the implementation of land use and building regulations and to define the role of the community in ensuring the safety of buildings and the environment especially at the project level through land-use practice.

Land-use practice should be applied as a risk reduction measure to ensure public safety and for the protection of the environment against exposure to hazards [147]. Land-use practice concerns the application of the provisions and regulations for zoning and land use planning control development in areas considered vulnerable [146]. Where communities are severely exposed to disaster risk, and as a last resort, government may introduce restrictions (buffer-zoning) and/or outright relocation of communities to safe havens. However, beneficiary communities should be adequately consulted and engaged in the hazard assessment and resettlement process to buy into the relocation. The involvement of beneficiary communities in the decision-making process would enable acceptability, long-term sustainability and success of a resettlement programme. For successful community relocation, measures such as geological studies and vulnerability assessments should be conducted and the issues of community safety, access to economic and livelihood opportunities, proximity to social infrastructure, physical security and safety of the relocation settlement must be adequately considered prior to relocation.

Rather than reproduce buildings to pre-disaster conditions, communities' exposure to health and safety risk should be mitigated through structural quality improvements and performance of buildings such that they resist the effects of exposure to hazard and do not harbour health and safety risk. To mitigate safety risk in housing reconstruction, effective regulations such as improved building codes and construction guidelines that guide building design, material and component selection and improved building production and management practice should be provided. The application of effective codes minimises human casualty and economic losses resulting from natural hazard exposure. Reconstruction agencies and management organisations should ensure compliance to standards by establishing quality assurance mechanisms that ensure the integration of established risk reduction measures during housing production and that housing quality does not compromise the approved codes, guidelines and designs provided. Compliance to design standards provides investors' confidence in housing reconstruction investments.

Salvaged materials and components are often put to use in housing reconstruction [8,9]. Some of the salvaged materials may contain hazardous substances that emanated from disaster conditions and which pose a health risk to reconstruction workers, beneficiaries and the environment $[38,41]$. To manage the exposure to such risks, health and safety experts should be deployed to reconstruction sites to assess salvaged materials and the reconstruction environment. Thereafter, identified health and safety concerns should be adequately communicated with precautionary measures proffered to the reconstruction management team to ensure hazard mitigation. Additionally, reconstruction organisations should ensure strict adherence to local building regulations and environmental codes on the use of certain materials to ensure the health and safety of workers and the beneficiary community.

To ensure safety in housing reconstruction, workers should be educated and equipped with the skills and knowledge required to mitigate health and safety risk. The capacity of workers should be enhanced regarding the social and technical requirements of reconstruction tasks and appropriate tools and equipment should be provided to enable workers to conduct their assigned tasks in a safe and effective manner. Personal Protective Equipment (PPE) to protect workers from exposure to on-site health and safety risks should be provided and their use enforced. Besides, risk and safe zones should be identified while signage detailing health and safety concerns are appropriately provided. As a further measure, insurance coverage should be provided for workers against any potential hazards to minimise the impact of losses that may occur.

From the synthesis of the collected evidence, we present the process of measures for managing health and safety issues in large-scale housing reconstruction in Figure 7. 


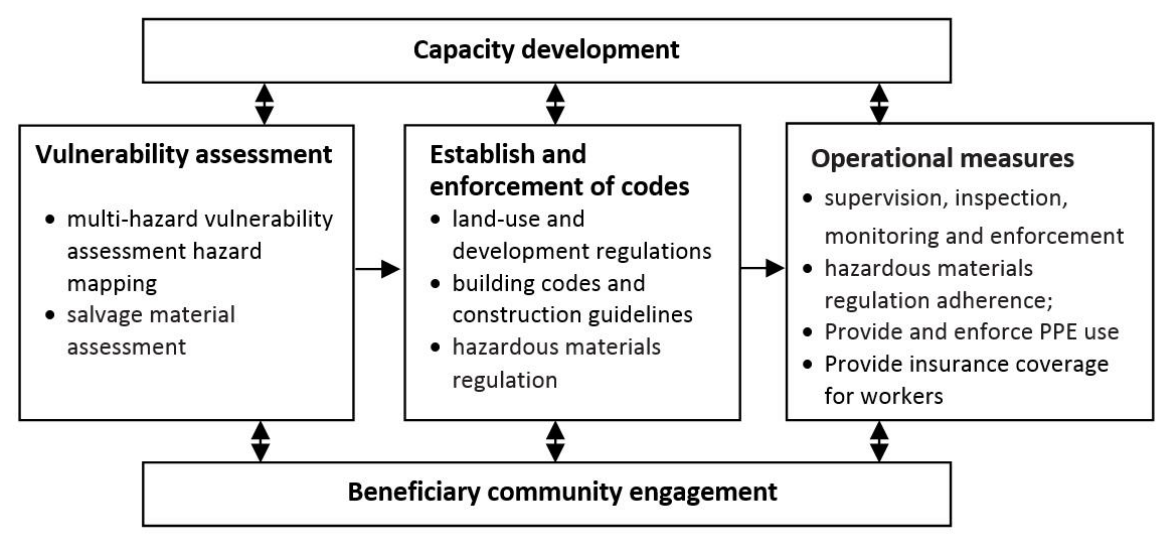

Figure 7. Measures to manage health and safety issues in post-disaster housing reconstruction.

\section{Conclusions}

Large-scale permanent housing reconstruction programmes are typically initiated to cushion the effects of disasters on housing and to facilitate the recovery of affected communities. However, particularly in developing countries, the implementation of housing interventions has often been ineffective and their intended outcomes have not been achieved. In earlier research, the ineffectiveness and failures of housing interventions have been linked to certain, specific management issues that arise in the context of post disaster reconstruction. The target of this study was to identify the measures that could be applied to manage these identified issues.

A comprehensive desktop study and synthesis of evidence from the literature enabled the identification of a number of measures that could be applied by management and implementing organisations to overcome the issues affecting housing reconstruction effectiveness. Four key measures for housing reconstruction programme effectiveness were drawn from the study:

1. Conducting assessments to determine the management needs that will enhance the housing reconstruction process and the achievement of the projects' outcomes;

2. Establishing and/or strengthening institutional and organisational structures and arrangements with adequately capable personnel deployed to effectively manage the processes involved in housing reconstruction;

3. Building the capacities of the participants involved in the reconstruction process, in particular, the management personnel and the beneficiary community to enable them to develop the requisite competencies for effectively managing the process and for the development of sustainable sources of livelihood;

4. The construction of resilient and acceptable housing to ensure disaster risk reduction, facilitate beneficiary community recovery and ensure the long-term sustainability and effectiveness of the housing programme.

Evidence also shows the importance of beneficiary engagement and participation in the housing reconstruction processes ranging from beneficiary involvement in the decision-making and implementation processes to participation in the building of their own houses to ensure resilience of the buildings and the recovery of beneficiary communities. The study relates to participatory large-scale permanent housing reconstruction programmes in low-income urban communities in developing countries.

The next stage of this research will subject the measures identified in this study to a validation process on the basis of expert opinion. It is intended that the resulting, validated measures will enable the development of a framework for the effective management of post-disaster housing reconstruction programmes. 
Acknowledgments: This research was supported by the Advancing Skill Creation to ENhance Transformation (ASCENT) project funded with support from the European Commission. The findings and opinions reported in this paper reflect the views only of the authors, and the Commission cannot be held responsible for any use which may be made of the information contained in it.

Author Contributions: Abdulquadri Ade Bilau is a PhD student and Emlyn Witt and Irene Lill are co-supervisors of his research. The overall research concept was developed in joint consultation and discussion. For this particular article, Abdulquadri Ade Bilau was the main author, Emlyn Witt assisted in developing the overall logic and structure of the article, writing some of the text and editing the manuscript. Irene Lill facilitated the research and the publication of this paper.

Conflicts of Interest: The authors declare no conflict of interest.

\section{References}

1. Audefroy, J.F. Post-Disaster emergency and reconstruction experiences in Asia and Latin America: An assessment. Dev. Pract. 2010, 20, 664-677. [CrossRef]

2. Barenstein, J.D.; Joshi, V.; Shinde, S.; Vyas, S.; Jadeja, Y. A Comparative Analysis of Six Housing Reconstruction Approaches in Post-Earthquake Gujarat; Sculoa Univeritaria Professionale della Svizzera Italiana: Lugano, Switzerland, 2005.

3. Hosseini, S.A.; de la Fuente, A.; Pons, O. Multicriteria Decision-Making Method for Sustainable Site Location of Post-Disaster Temporary Housing in Urban Areas. J. Constr. Eng. Manag. 2016, 142, 04016036. [CrossRef]

4. Hayles, C.S. An examination of decision making in post disaster housing reconstruction. Int. J. Dis. Resil. Built Environ. 2010, 1, 103-122. [CrossRef]

5. Lyons, M. Building Back Better: The Large-Scale Impact of Small-Scale Approaches to Reconstruction. World Dev. 2009, 37, 385-398. [CrossRef]

6. Daly, P.; Brassard, C. Aid accountability and participatory approaches in post-disaster housing reconstruction1. Asian J. Soc. Sci. 2011, 39, 508-533. [CrossRef]

7. Barenstein, J.D. Housing Reconstruction in Post-Earthquake Gujarat: A Comparative Analysis; Humanitarian Practice Network; Overseas Development Institute: London, UK, 2006.

8. Barenstein, J.D.; Pittet, D. Post-Disaster Housing Reconstruction: Current Trends and Sustainable Alternatives for Tsunami-Affected Communities in Coastal Tamil Nadu; Institute for Applied Sustainability to the Built Environment, University of Applied Sciences of Southern Switzerland: Canobbio, Switzerland, 2007.

9. Haigh, R.; Amaratunga, D. An integrative review of the built env. discipline's role in the development of society's resilience to disasters. Int. J. Disaster Resil. Built Environ. 2010, 1, 11-24. [CrossRef]

10. Amin Hosseini, S.M.; de la Fuente, A.; Pons, O. Multi-criteria decision-making method for assessing the sustainability of post-disaster temporary housing units technologies: A case study in Bam, 2003. Sustain. Cit. Soc. 2016, 20, 38-51. [CrossRef]

11. Ahmed, I. An overview of post-disaster permanent housing reconstruction in developing countries. Int. J. Disaster Resil. Built Environ. 2011, 2, 148-164. [CrossRef]

12. Berke, P.; Smith, G.; Lyles, W. Planning for resiliency: Evaluation of state hazard mitigation plans under the disaster mitigation act. Nat. Hazards Rev. 2012, 13, 139-149. [CrossRef]

13. Berke, P.R.; Campanella, T.J. Planning for postdisaster resiliency. Ann. Am. Acad. Political Soc. Sci. 2006, 604, 192-207. [CrossRef]

14. Barakat, S. Housing reconstruction after conflict and disaster. Humanit. Policy Group Netw. Pap. 2003, 43, $1-40$.

15. International Federation of Red Cross (IFRC). Owner-Driven Housing Reconstruction Guidelines; IFRC: New York, NY, USA, 2010; p. 208.

16. United Nations Office for Disaster Risk Reduction (UNISDR). Sendai Framework for Disaster Risk Reduction 2015-2030; United Nations Office for Disaster Risk Reduction: Geneva, Switzerland, 2015.

17. Dynes, R.R.; Quarantelli, E. A Brief Note on Disaster Restoration, Reconstruction and Recovery: A Comparative Note Using Post Earthquake Observations; Disaster Research Center: Newark, DE, USA, 2008.

18. Bilau, A.A.; Witt, E. An analysis of issues for the management of post-disaster housing reconstruction. Int. J. Strateg. Prop. Manag. 2016, 20, 265-276. [CrossRef]

19. Mannakkara, S.; Wilkinson, S. Build Back Better: Lessons from Sri Lanka's Recovery from the 2004 Indian Ocean Tsunami. ArchNet-IJAR Int. J. Archit. Res. 2013, 7, 108-121. 
20. Ophiyandri, T.; Amaratunga, D.; Pathirage, C.; Keraminiyage, K. Critical success factors for community-based post-disaster housing reconstruction projects in the pre-construction stage in Indonesia. Int. J. Disaster Resil. Built Environ. 2013, 4, 236-249. [CrossRef]

21. Davidson, C.H.; Johnson, C.; Lizarralde, G.; Dikmen, N.; Sliwinski, A. Truths and myths about community participation in post-disaster housing projects. Habitat Int. 2007, 31, 100-115. [CrossRef]

22. Liu, L.; Liu, J. Experience of the post-disaster housing rehabilitation and reconstruction in Wudu District, Longnan City. In Proceedings of the 17th International Symposium on Advancement of Construction Managment and Real Estate; Springer: Berlin/Heidelberg, Germany, 2014.

23. Bilau, A.A.; Witt, E.; Lill, I. A Framework for Managing Post-disaster Housing Reconstruction. Procedia Econ. Financ. 2015, 21, 313-320. [CrossRef]

24. Battisto, D.; Franqui, D. A Standardized Case Study Framework and Methodology to Identify "Best Practices". In Proceedings of the ARCC Conference Repository, Honolulu, HI, USA, 12-15 February 2014.

25. Ulrich, S.R. Evidence-based health-care architecture. Lancet Med. Creativity 2006, 368, S38-S39. [CrossRef]

26. Skat-International Federation of Red Cross and Red Crescent Societie (IFRC). Sustainable reconstruction in Urban Areas. In Sustainable Reconstruction in Urban Areas; IFRC: New York, NY, USA, 2012.

27. Tabassi, A.A.; Bakar, A.H.A. Training, motivation, and performance: The case of human resource management in construction projts in Mashhad, Iran. Int. J. Proj. Manag. 2009, 27, 471. [CrossRef]

28. Project Management Institute. A Guide to the Project Management Body of Knowledge (PMBOK ${ }^{\circledR}$ Guide), 5th ed.; Project Management Institute: Newtown Square, PA, USA, 2015.

29. Jayasuriya, S.; McCawley, P. Reconstruction after a Major Disaster: Lessons from the Post-Tsunami Experience in Indonesia, Sri Lanka, and Thailand; Asian Development Bank (ADB) Institute: Tokyo, Japan, 2008.

30. World Bank, and Global Facility for Disaster Risk Reduction (WB-GFDRR). Pdna Guidelines Volume B—Housing. Available online: http://www.recoveryplatform.org/assets/projects/PDNA/PDNAVolumeB/WB_UNDP_ PDNA_Housing_SP_FINAL.pdf (accessed on 26 March 2017).

31. Turner John, F. Housing by People: Towards Autonomy in Building Environment; Marion Boyars: London, UK, 1976; pp. 6-7.

32. United States Agency for International Development (USAID). Final Report on Activities and Results: Coffee Zone Reconstruction Program; USAID: Washington, DC, USA, 2002.

33. Ferguson, B.; Navarrete, J. A financial framework for reducing slums: Lessons from experience in Latin America. Environ. Urban. 2003, 15, 201-216. [CrossRef]

34. Ettouney, S.; Abdel-Kader, N. Users' participation in low cost housing projects post occupancy evaluation. Int. J. Hous. Appl. 2003, 27, 333-343.

35. Da Silva, J. Lessons from Aceh: Key Considerations in Post-Disaster Reconstruction; Practical Action Publishing: Warwickshire, UK, 2010.

36. Gharaati, M.; Davidson, C. Who Knows Best? An Overview of Reconstruction after the Earthquake in Bam, Iran. In Proceedings of the 4th International i-Rec Conference 2008 Building Resilience: Achieving Effective Post-Disaster Reconstruction, Christchurch, New Zealand, 30 April-2 May 2008.

37. Badan Rehabilitasi \& Rekonstruksi NAD-Nias. Aceh And Nias Two Years After the Tsunami: 2006 Progress Report; Badan Rehabilitasi \& Rekonstruksi NAD-Nias: Banda Aceh, Indonesia, 2006.

38. Kennedy, J.; Ashmore, J.; Babister, E.; Kelman, I. The meaning of 'build back better': Evidence From post-tsunami Aceh and Sri Lanka. J. Conting. Crisis Manag. 2008, 16, 24-36. [CrossRef]

39. Boano, C. Housing anxiety and multiple geographies in post-tsunami Sri Lanka. Disasters 2009, 33, 762-785. [CrossRef] [PubMed]

40. Pathiraja, M.; Tombesi, P. Towards a more "robust" technology? Capacity building in post-tsunami Sri Lanka. Disaster Prev. Manag. Int. J. 2009, 18, 55-65. [CrossRef]

41. Jha, A.K. Handbook for Post-Disaster Housing and Community Reconstruction; World Bank: Washington, DC, USA, 2009.

42. Haigh, R.; Sutton, R. Strategies for the effective engagement of multi-national construction enterprises in post-disaster building and infrastructure projects. Int. J. Disaster Resil. Built Environ. 2012, 3, 270-282. [CrossRef]

43. Chang-Richards, A.; Wilkinson, S.; Seville, E.; Brunsdon, D. Myths and Realities of Reconstruction Workers' Accommodation; Resilient Organisations: Auckland, New Zealand, 2013.

44. Steinberg, F.; Smidt, P. Rebuilding Lives and Homes in Aceh and Nias, Indonesia; Asian Development Bank: Metro Manila, Philippines, 2010. 
45. Shaw, J.; Ahmed, I. Design and Delivery of Post-Disaster Housing Resettlement Programs; Case Studies from Sri Lanka and India Report; RMIT University: Melbourne, Australia, 2010.

46. Chang-Richards, Y.; Wilkinson, S.; Seville, E.; Brunsdon, D. A systems approach to managing human resources in disaster recovery projects. In Proceedings of the 5th International Conference on Building Resilience, Newcastle, Australia, 15-17 July 2015.

47. Piri, I.S.; Chang-Richards, Y.; Wilkinson, S. Skills shortages in the christchurch subcontracting sector. In Proceedings of the 5th International Conference on Building Resilience, Newcastle, Australia, 15-17 July 2015.

48. Barenstein, J. Challenges and risks in post-tsunami housing reconstruction in Tamil Nadu. Humanit. Exchang. 2006, 33, 38-39.

49. Chan, P.W.; Dainty, A.R. Resolving the UK construction skills crisis: A critical perspective on the research and policy agenda. Constr. Manag. Econ. 2007, 25, 375-386. [CrossRef]

50. Bosher, L.; Carrillo, P.; Dainty, A.; Glass, J.; Price, A. Realising a resilient and sustainable built environment: Towards a strategic agenda for the United Kingdom. Disasters 2007, 31, 236-255. [CrossRef] [PubMed]

51. Sui Pheng, L.; Raphael, B.; Kit, W.K. Tsunamis: Some pre-emptive disaster planning and management issues for consideration by the construction industry. Struct. Surv. 2006, 24, 378-396. [CrossRef]

52. World Bank. Overall Reconstruction: Design, Implementation and Management; World Bank Good Practice Notes; World Bank: Washington, DC, USA, 2008.

53. Bosher, L.; Dainty, A.; Carrillo, P.; Glass, J.; Price, A. Integrating disaster risk management into construction: A UK perspective. Build. Res. Inf. 2007, 35, 163-177. [CrossRef]

54. Lyons, M.; Schilderman, T. (Eds.) Building Back Better, Delivering People-centred Housing Reconstruction at Scale; Practical Action Publishing: Rugby, UK, 2010.

55. Schilderman, T.; Lyons, M. Resilient dwellings or resilient people? Towards people-centred reconstruction. Environ. Hazards 2011, 10, 218-231. [CrossRef]

56. Ingirige, M.; Haigh, R.P.; Malalgoda, C.I.; Palliyaguru, R.S. Exploring good practice knowledge transfer related to post tsunami housing re-construction in Sri Lanka. J. Constr. Dev. Cries. 2008, 13, 21-42.

57. Gharaati, M. An Overview of the Reconstruction Program after the Earthquake of Bam, Iran. In Proceedings of the I-Rec 2006 International Conference on Post-Disaster Reconstruction: Meeting Stakeholder Interests, Florence, Italy, 17-19 May 2006.

58. Burleson, R.C.; Haas, C.T.; Tucker, R.L.; Stanley, A. Multiskilled labor utilization strategies in construction. J. Constr. Eng. Manag. 1998, 124, 480-489. [CrossRef]

59. Koria, M. Managing for innovation in large and complex recovery programmes: Tsunami lessons from Sri Lanka. Int. J. Proj. Manag. 2009, 27, 123-130. [CrossRef]

60. Mannakkara, S.; Wilkinson, S. Build Back Better Applications for Stakeholder Management in Post-Disaster Environments; Earthquake Engineering Research Institute: Oakland, CA, USA, 2013.

61. Ophiyandri, T.; Amaratunga, R.; Pathirage, C. Risk Identification on Community Based Post Disaster Housing Reconstruction Projects. In Proceedings of the International Conference on Building Resilience 2011: Interdisciplinary Approaches to Disaster Risk Reduction, and the Development Of Sustainable Communities And Cities, Kandalama, Sri Lanka, 19-21 July 2011.

62. Trohanis, Z.; Read, G. Housing Reconstruction in Urban and Rural Areas; The World Bank: Washington, DC, USA, 2010.

63. Benson, R.; Twigg, J. Tools For Mainstreaming Disaster Risk Reduction. In Guidance Note 12; ProVention Consortium Secretariat: Geneva, Switzerland, 2007.

64. Build Change. Homeowner-Driven Housing Reconstruction and Retrofitting in Haiti: Lessons Learned, 4 Years after the Earthquake; Build Change: Denver, CO, USA, 2014.

65. Fallahi, A. Lessons learned from the housing reconstruction following the Bam earthquake in Iran. Aust. J. Emerg. Manag. 2007, 22, 26.

66. Tas, M.; Tas, N.; Cosgun, N. Study on permanent housing production after 1999 earthquake in Kocaeli (Turkey). Disaster Prev. Manag. Int. J. 2010, 19, 6-19. [CrossRef]

67. Ophiyandri, T. Community-Based Post-Disaster Housing Reconstruction: Examples from Indonesia. In Post-Disaster Reconstruction of the Built Environment: Rebuilding for Resilience; John Wiley \& Sons, Inc.: Somerset, NJ, USA, 2011; pp. 91-116.

68. Ophiyandri, T.; Amaratunga, R.; Pathirage, C. Community Based Post Disaster Housing Reconstruction: Indonesian Perspective. In Proceedings of the CIB 2010, Salford, UK, 10-13 May 2010. 
69. UN-Habitat. Aceh-Nias Housing \& Settlements Reconstruction Newsletter; UN-HABITAT: Banda, Aceh, Indonesia, 2009.

70. Unsyiah (Universitas Syiah Kuala) and UN-Habitat. Post Tsunami Settlement Recovery Monitoring in Aceh; Banda, Aceh, Indonesia, 2006.

71. Bilau, A.A.; Witt, E.; Lill, I. Housing reconstruction following the 2012 nigerian floods: Was it built back better? In Proceedings of the CIB World Building Congress 2016: Volume II, Tampere, Finland, 30 May-3 June 2016.

72. Thayaparan, M.; Siriwardena, M.; Malalgoda, C.I.; Amaratunga, D.; Lill, I.; Kaklauskas, A. Enhancing post-disaster reconstruction capacity through lifelong learning in higher education. Disaster Prev. Manag. Int. J. 2015, 24, 338-354. [CrossRef]

73. Von Meding, J.; Oyedele, L.; Bruen, J. Linking Organisational Competency to Project Success in Post-disaster Reconstruction. Open House Int. 2014, 39, 9-18.

74. Telford, J.; Cosgrave, J.; Houghton, R. Joint Evaluation of the International Response to the Indian Ocean Tsunami. Synthesis Report. 2006. Available online: www.sida.se/publications (accessed on 9 March 2016).

75. Lin Moe, T.; Pathranarakul, P. An integrated approach to natural disaster management: Public project management and its critical success factors. Disaster Prev. Manag. 2006, 15, 396-413. [CrossRef]

76. United Nations Office for the Coordination of Humanitarian Affairs (UN/OCHA). Transitional Settlement and Reconstruction After Natural Disasters; United Nation: New York, NY, USA, 2008.

77. Oxfam. Beyond Brick and Mortar: Hand Book on Approaches to Permanent Shelters in Humanitarian Response; India Tsunami Response Experience; Oxfam International: Oxford, UK, 2008.

78. Berke, P.; Godschalk, D. Searching for the good plan A meta-analysis of plan quality studies. J. Plan. Lit. 2009, 23, 227-240. [CrossRef]

79. Thorburn, C. The Acehnese Gampong Three Years On: Assessing Local Capacity and Reconstruction Assistance in Post-Tsunami Aceh; Aceh Community Assistance Research Project (ACARP): Banda, Aceh, Indonesia, 2007.

80. Ghafory-Ashtiany, M.; Hosseini, M. Post-Bam earthquake: Recovery and reconstruction. Nat. Hazards 2008, 44, 229-241. [CrossRef]

81. Da Silva, J.; Batchelor, V. Indonesia: Understanding Agency Policy in a National Context. In Building Back Better: Delivering People-centred Housing Reconstruction at Scale; Practical Action Publishing: Rugby, UK, 2010; p. 135.

82. ALNAP. Literature Review for Shelter after Disaster. 2011. Available online: http://www.alnap.org/ resource/7725 (accessed on 9 March 2016).

83. Fengler, W.; Ihsan, A.; Kaiser, K. Managing Post-Disaster Reconstruction Finance; World Bank Publications: Washington, DC, USA, 2008.

84. Ranghieri, F.; Ishiwatari, M. Reconstruction in the Tohoku Area; The World Bank: Washington, DC, USA, 2014.

85. Wilkinson, S.; Chang-Richards, A.; Sapeciay, Z.; Costello, S.B.; Haigh, R. Improving construction sector resilience. Int. J. Disaster Resil. Built Environ. 2016, 7, 173-185. [CrossRef]

86. Steinberg, F. Housing reconstruction and rehabilitation in Aceh and Nias, Indonesia-Rebuilding lives. Habitat Int. 2007, 31, 150-166. [CrossRef]

87. UN-Habitat. Post-Tsunami Aceh Nias Settlement and Housing Recovery Review; UN-Habitat: Banda, Aceh, Indonesia, 2009.

88. Olshansky, R.B. How do communities recover from disaster? A review of current knowledge and an agenda for future research. In Proceedings of the 46th Annual Conference of the Association of Collegiate Schools of Planning, Kansas City, MO, USA, 27-30 October 2005.

89. Johnson, L. Empowering local governments in disaster recovery management: Lessons from Watsonville and Oakland in recovering from the 1989 Loma Prieta earthquake and other recent disasters. Lessons Learn. Over Time 1999, 1, 41-84.

90. UN-Habitat. People's Process in Post-disaster and Post-conflict Recovery and Reconstruction; UN-Habitat: Banda, Aceh, Indonesia, 2008.

91. Drabek, T.E.; McEntire, D.A. Emergent phenomena and multiorganizational coordination in disasters: Lessons from the research literature. Int. J. Mass Emerg. Disasters 2002, 20, 197-224.

92. McKeon, J.; Masyrafah, H. Post Tsunami Aid Effectiveness in Aceh: Proliferation and Coordination in Reconstruction; Working Paper; Wolfensohn Center for Development: Washington, DC, USA, 2008.

93. Department for International Development (DFID). Shelter after Disaster. 2010. Available online: http:/ / www.sheltercasestudies.org/files/SC-OCHA-DfID (accessed on 12 September 2016). 
94. Ranghieri, F.; Ishiwatari, M. Learning from Megadisasters: Lessons from the Great East Japan Earthquake; World Bank Publications: Washington, DC, USA, 2014.

95. Minervini, C. Housing reconstruction in Kosovo. Habitat Int. 2002, 26, 571-590. [CrossRef]

96. Twigg, J. Characteristics of a Disaster-Resilient Community: A Guidance Note; Version 1; The DFID Disaster Risk Reduction Interagency Coordination Group; University College London: London, UK, 2007.

97. Berke, P.R.; Kartez, J.; Wenger, D. Recovery after disaster: Achieving sustainable development, mitigation and equity. Disasters 1993, 17, 93-109. [CrossRef] [PubMed]

98. Government of Sri Lanka and United Nations Colombo (GoSL and UN). National Post-Tsunami Lessons Learned and Best Practices Workshop; Government of Sri Lanka and United Nations Colombo: Colombo, Sri Lanka, 2005.

99. Steins, N.A.; Edwards, V.M. Platforms for collective action in multiple-use common-pool resources. Agric. Hum. Values 1999, 16, 241-255. [CrossRef]

100. Gajendran, T.; Mackee, J.; Brewer, G.; Giggins, H.; LeGoff, R. Organising the Management of Disaster Recovery and Construction: A Built Environment Perspective. In International Conference on Building Resilience: Individual, Institutional and Societal Coping Strategies; Hall, M., Amaratunga, D., Haigh, R., Bingu, I., Keraminiyage, K., Kulatunga, U., Pathirage, C., Eds.; Ahungalla, Sri Lanka: Centre for Disaster Resilience, The University of Salford: Salford, UK, 2013.

101. Faysse, N. Troubles on the way: An analysis of the challenges faced by multi-stakeholder platforms. Nat. Resour. Forum 2006, 30, 219-229. [CrossRef]

102. Shelter Center. Literature Review for Shelter after Disaster; Shelter Center: Geneva, Switzerland, 2011.

103. Baroudi, B.; Rapp, R.R. Stakeholder management in disaster restoration projects. Int. J. Disaster Resil. Built Environ. 2014, 5, 182-193. [CrossRef]

104. Fan, L. Disaster as Opportunity? Building Back Better in Aceh, Myanmar and Haiti; Overseas Development Institute: London, UK, 2013.

105. Twigg, J. Characteristics of a Disaster-Resilient Community: A Guidance Note; Version 2; University College London: London, UK, 2009.

106. Al-Khafaji, A.W.; Oberhelman, D.R.; Baum, W.; Koch, B. Communication in stakeholder management. In Construction Stakeholder Management; Wiley-Blackwell: Chichester, UK, 2009; p. 159.

107. KPMG. Stakeholder Communications: The Toolkit. Available online: https://home.kpmg.com/ca/en/ home/insights/2016/03/stakeholder-communication.html (accessed on 26 March 2017).

108. Olander, S. Stakeholder impact analysis in construction project management. Constr. Manag. Econ. 2007, 25, 277-287. [CrossRef]

109. Jha, A.K.; Duyne, J.E. Safer Homes, Stronger Communities: A Handbook for Reconstructing after Natural Disasters; World Bank Publications: Washington, DC, USA, 2010.

110. Tagliacozzo, S.; Magni, M. Communicating with communities during post-disaster reconstruction: An initial analysis. Nat. Hazards 2016, 84, 2225. [CrossRef]

111. Australian Red Cross. Communicating in Recovery; Australian Red Cross: Carlton, Australia, 2010.

112. Attalla, M.; Hegazy, T.; Elbeltagi, E. In-house delivery of multiple-small reconstruction projects. J. Manag. Eng. 2004, 20, 25-31. [CrossRef]

113. Chang, Y.; Wilkinson, S.; Potangaroa, R.; Seville, E. Donor-driven resource procurement for post-disaster reconstruction: Constraints and actions. Habitat Int. 2011, 35, 199-205. [CrossRef]

114. Chang, Y.; Wilkinson, S.; Potangaroa, R.; Seville, E. Resourcing for Post-Disaster Reconstruction: A Comparative Study of Indonesia and China. Disaster Prev. Manag. 2012, 21, 7-21. [CrossRef]

115. European Commission. Partnership in Kosovo: Reconstruction 1999-2000: An Overview by the Department of Reconstruction; European Commission: Brussels, Belgium, 2001.

116. Singh, B. Availability of Resources for State Highway Reconstruction: A Wellington Earthquake Scenario. Mater's Thesis, University of Auckland, Auckland, New Zealand, 2007.

117. Tserng, H.P.; Yin, S.Y.; Li, S. Developing a resource supply chain planning system for construction projects. J. Constr. Eng. Manag. 2006, 132, 393-407. [CrossRef]

118. Kovács, G.; Matopoulos, A.; Hayes, O. A community-based approach to supply chain design. Int. J. Logist. Res. Appl. 2010, 13, 411-422. [CrossRef]

119. Nazara, S.; Resosudarmo, B.P. Aceh-Nias Reconstruction and Rehabilitation: Progress and Challenges at the End of 2006; ADB Institute Discussion Papers; Asian Development Bank (ADB) Institute: Tokyo, Japan, 2007. 
120. Chang, Y.; Wilkinson, S.; Potangaroa, R.; Seville, E. Resourcing challenges for post-disaster housing reconstruction: A comparative analysis. Build. Res. Inf. 2010, 38, 247-264. [CrossRef]

121. Oxfam. Guidelines for Post Disaster Housing. 2003. Available online: http://www.ifrc.org/PageFiles/ 95751/B.d.03.\%20Guidelines\%20for\%20Post\%20Disaster\%20Housing\%20\%20version\%201_OXFAM\% 20GB.pdf (accessed on 9 March 2016).

122. Chang, Y.; Wilkinson, S.; Brunsdon, D.; Seville, E.; Potangaroa, R. An integrated approach: Managing resources for post-disaster reconstruction. Disasters 2011, 35, 739-765. [CrossRef] [PubMed]

123. European Commission; World Bank. Toward Stability and Prosperity: A Program for Reconstruction and Recovery in Kosovo; European Commission: Brussels, Belgium, 1999.

124. Long, D.C.; Wood, D.F. The logistics of famine relief. J. Bus. Logist. 1995, 16, 213.

125. Pande, R.K.; Pande, R. Resettlement and rehabilitation issues in Uttaranchal (India) with reference to natural disasters. Disaster Prev. Manag. Int. J. 2007, 16, 361-369. [CrossRef]

126. Kovács, G.; Matopoulos, A.; Hayes, O. Designing Post-Disaster Supply Chains: Learning from Housing Reconstruction Projects. In Supply Chain Management: Concepts, Methodologies, Tools, and Applications; IGI Global: Hershey, PA, USA, 2013; pp. 1043-1055.

127. Zuo, K.; Wilkinson, S.; Rotimi, J.O. Building Abroad: Procurement of Constr and Reconstr Projs in the International Context; IF Research Group-grif: Montreal, Canada, 2008.

128. Chang, Y.; Wilkinson, S.; Potangaroa, R.; Seville, E. Identifying factors affecting resource availability for post-disaster reconstruction: A case study in China. Constr. Manag. Econom. 2011, 29, 37-48. [CrossRef]

129. Zuo, K.; Wilkinson, S. Supply chain and material procurement for post disaster construction: The Boxing Day Tsunami reconstruction experience in Aceh, Indonesia. In Proceedings from International Conference on Building Education and Research; University of Salford: Salford, UK, 2008.

130. Limoncu, S.; Celebioglu, B. Post-disaster sustainable housing system in Turkey. In Proceedings of the i-Rec 2006 International Conference on Post-Disaster Reconstruction: Meeting Stakeholder Interests, Florence, Italy, 17-19 May 2006.

131. Kekre, S.; Murthi, B.; Srinivasan, K. Operating decisions, supplier availability and quality: An empirical study. J. Oper. Manag. 1995, 12, 387-396. [CrossRef]

132. Pilling, B.K.; Zhang, L. Cooperative exchange: Rewards and risks. J. Supply Chain Manag. 1992, $28,2$.

133. Mannakkara, S.; Wilkinson, S.; Francis, T.R. "Build Back Better" principles for reconstruction. In Encyclopedia of Earthquake Engineering; Beer, M., Kougioumtzoglou, I.A., Patelli, E., Au, S.-K., Eds.; Springer: Berlin/Heidelberg, Germany, 2015; pp. 1-12.

134. Reliefweb. Indonesia: Rehabilitation and Reconstruction Agency for Aceh and Nias; BRR-Badan Rehabilitasi dan Rekonstruksi NAD-Nias: Banda Aceh, Indonesia, 2005.

135. Rohland, K.; Cliffe, S. The East Timor Reconstruction Program: Successes, Problems And Tradeoffs; World Bank, Conflict Prevention and Reconstruction Unit: Washington, DC, USA, 2002.

136. Manelele, I.; Muya, M. Risk identification on community-based construction projects in Zambia. J. Eng. Des. Technol. 2008, 6, 145-161.

137. Dercon, B.; Kusumawijaya, M. Two Years of Settlement and Recovery in Aceh and Nias: What Should the Planners Have Learned; UN-Habitat: Geneva, Switzerland, 2007; Available online: http:/ / www.unhabitat-indonesia. org/publication/index.htm (accessed on 2 November 2009).

138. Flint, M.; Goyder, H. Funding the Tsunami Response; Tsunami Evaluation Coalition: London, UK, 2006.

139. Olshansky, R.B.; Hopkins, L.D.; Johnson, L.A. Disaster and recovery: Processes compressed in time. Nat. Hazards Rev. 2012, 13, 173-178. [CrossRef]

140. Pantelić, J. The link between reconstruction and development. Land Use Policy 1991, 8, 343-347. [CrossRef]

141. The World Bank. Building Regulation for Resilience: Managing Risks for Safer Cities; The World Bank: Washington, DC, USA, 2015.

142. Benson, C.; Twigg, J.; Rossetto, T. Tools for Mainstreaming Disaster Risk Reduction: Guidance Notes For Development Organisations; Provention Consortium: Geneva, Switzerland, 2007.

143. Oliver-Smith, A. Successes and failures in post-disaster resettlement. Disasters 1991, 15, 12-23. [CrossRef] [PubMed]

144. Disaster Assessment Portal. Techniques Used in Disaster Risk Assessment. Available online: http://www. disasterassessment.org/section.asp?id=20 (accessed on 11 September 2016). 
145. Godschalk, D.R. Urban hazard mitigation: Creating resilient cities. Nat. Hazards Rev. 2003, 4, $136-143$. [CrossRef]

146. Wu, J.Y.; Lindell, M.K. Housing Reconstruction After Two Major Earthquakes: The 1994 Northridge Earthquake in the United States and the 1999 Chi-Chi Earthquake in Taiwan. Disasters 2004, 28, 63-81. [CrossRef] [PubMed]

147. Wamsler, C. Mainstreaming risk reduction in urban planning and housing: A challenge for international aid organisations. Disasters 2006, 30, 151-177. [CrossRef] [PubMed]

148. Ibrahim, I.; Muibi, K.; Alaga, A.; Babatimehin, O.; Ige-Olumide, O.; Mustapha, O.; Hafeez, S. Suitability Analysis of Resettlement Sites for Flood Disaster Victims in Lokoja and Environs. World Environ. 2015, $5,101-111$.

149. Maly, E.; Ishikawa, E. Planning for relocation in recovery after the Great East Japan Earthquake: Considering residential relocation in contexts. Int. J. Disaster Resil. Built Environ. 2014, 5, 243-259. [CrossRef]

150. Dias, N.T.; Keraminiyage, K.; DeSilva, K.K. Long-term satisfaction of post disaster resettled communities: The case of post tsunami-Sri Lanka. Disaster Prev. Manag. Int. J. 2016, 25, 581-594. [CrossRef]

151. Lovegrove, K.; Moullier, T. World Bank's Groundbreaking Report on Resilient Building Construction News; World Bank: Washington, DC, USA, 2016.

152. Catholic Relief Services. Managing Post-Disaster Reconstruction Projects; Grafweg, A., Ed.; Catholic Relief Services: Baltimore, MD, USA, 2012; p. 132.

153. Chang, Y.; Wilkinson, S.; Potangaroa, R.; Seville, E. Managing resources in disaster recovery projects. Eng. Constr. Archit. Manag. 2012, 19, 557-580. [CrossRef]

154. Maxwell, D.; Walker, P.; Church, C.; Harvey, P.; Savage, K.; Bailey, S.; Hees, R.; Ahlendorf, M. Preventing Corruption in Humanitarian Assistance: Final Research Report; Transparency International: Berlin, Germany, 2008.

155. Transparency International (TI). Global Corruption Report: Corruption in Construction and Post-Conflict Reconstruction; Transparency International: Berlin, Germany, 2005.

156. Stansbury, N. Exposing the Foundations of Corruption in Construction; Global Corruption Report; Transparency International: Berlin, Germany, 2005; pp. 36-38.

(C) 2017 by the authors. Licensee MDPI, Basel, Switzerland. This article is an open access article distributed under the terms and conditions of the Creative Commons Attribution (CC BY) license (http:/ / creativecommons.org/licenses/by/4.0/). 